\title{
1.916 \\ D 298
}

Davis.

Fall And Winter Characters In Some Species Of Malus

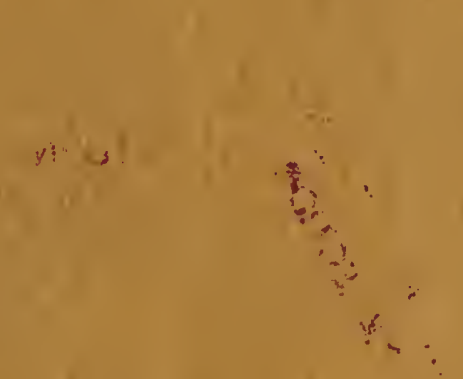





\section{FALL AND WINTER CHARACTERS IN SOME SPECIES OF MALÚS}

BY

ROBERT LESLEY DAVIS

A. B. University of Nebraska, 1914

THESIS

Submitted in Partial Fulfillment of the Requirements for the

Degree of

MASTER OF ARTS

IN BOTANY

IN

THE GRADUATE SCHOOL

OF THE

UNIVERSITY OF ILLINOIS

1916 



\section{U N I VERS I T Y OF ILLINOIS \\ THE GRADUATE SCHOOL}

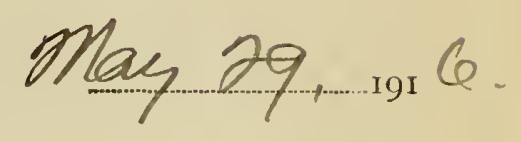

I HEREBY RECOMMEND THAT THE THESIS PREPARED UNDER MY SUPER-

VISION BY Fobert I.:-osley Javis

ENTITLED Fall and "inter Characters in some inecies of

Malus

BE ACCEPTED AS FULFILLING THIS PART OF THE REQUIREMENTS FOR THE DEGREE OF Master of Arts

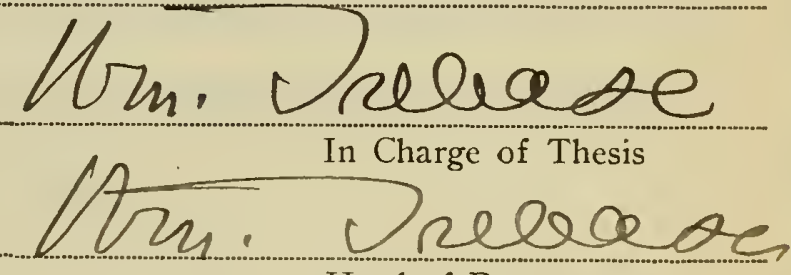

Head of Department

Recommendation concurred in :*

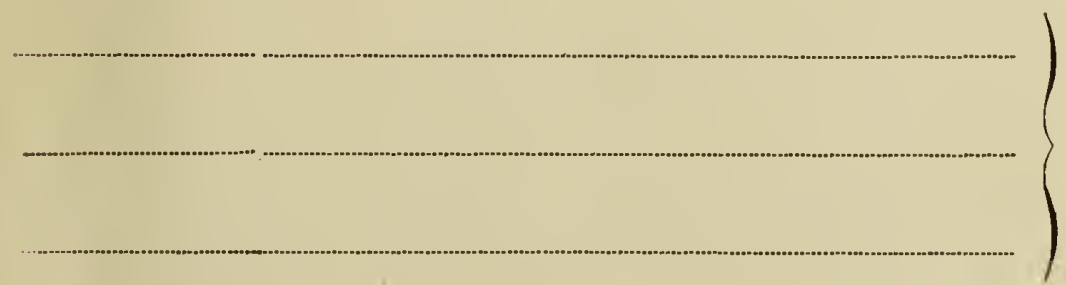

Committee

on

Final Examination*

*Required for doctor's degree but not for master's. 



\title{
ACKNONLEDGIMENTS.
}

\author{
**** \\ Acknowledgements are due to Dr. Wm. Trelease for his nice \\ criticisms and helpful advice. I am indebted to Mr. B. E. Cuick, \\ Mr. John A. Elliott, and Mr. F. B. Kempton for material help in \\ photography. The members of the horticultural department were \\ very kind in furnishing me with material from which to collect \\ and I take this means of thanking them.
}



Table of contents.

\section{Introduction}

II Key

II Description with illustrations

IV Bibliography 
Digitized by the Internet Archive in 2013 


\section{Introduction.}

\section{"Fall and Winter Characters in Some Species of Malus."}

Iittle attention has been bestovied upon the characters of plants other than those of fruit and flower. The limited flowering and fruiting period of a plant limits in turn the time during which the plant can be worked at and pigeon-holed correctly by those characters. A study of sixteen species of lialus, some native, others, from Russia, and some Irom Japan, furnish the basis for this paper. Twigs and leaves were collected two seasons to aviod variation due to environmental conditions. Leaves were collected in September 1915 and September 1916, the twigs in February 1915 and February 1916. The trees are of the same age and all grafted on common cider-mill apple stock; the scions were obtained from the Arnold Arboretum. The fact that the trees could not be studied in their wild state rather detracts from the fundamental nature of the work.

A tentative key follows this introduction with descriptions and photographs of drawings of each species. The key has been rounded out by using both leaf and twig characters. Most of the twig characters with the exception of the persistence of twig pubescence, and the typical winter bud shape, can be made out in the fall if the leaves are carefully dissected so as to disclose the axillary buds.

The leaves were studied by the use of four types; terminal vegetative leaves, middle vegetative leaves, terminal fruit spur leaves, and basal fruit spur leaves. The value of this rests in 

the varying degree in which pubescence and general leaf shape show up on the fruit spur leaves. Sometimes leaf lobing shows up even in the terminal fruit spur leaves as with Malus ioensis and in other instances it does not show up to any marked degreo. Pubescence is generally not persistent on fruit spur leaves but where the leaves of a species are, so to speak, typically "smothered" with pubescence the fruit spur leaves show this also. The general shape of these four types is quite the same for all the species; mostly elliptical or ovate with the vegetative leaves, and mostly lanceolate with the terminal fruit spur leaves. The basal fruit spur leaves because of their abortive nature can be neglected aside from the study of the pubescence character. About forty leaves, ten of each type, were mounted for each species on celluloid, so that for pubescence and gland study both sides of the leaves were open for examination. Leaf lobing is interesting as some of the species are recognized as being hybrids between deeply lobed and entire leafed species. Instead of normal segregation you have variability somewhat as it appears is sassafras. In the cross of Urtica pilulifera vith U. Dodarti the normal monohybrid segregation occurs. The Urtica pilulifera serrate type of leaf is "dominant" in the $F_{1}$, with three serrate to one wavy margined like Urtica Dodarti in the $\mathrm{F}_{2}{ }^{*}$. In two species of apples Malus floribunda, and Malus atrosanguinea the same tree bears even on the same twig, leaves lobed on one side, leaves lobed on two sides, and entire leaves. In the cross of the wild species, citrus trifoliata, onto the orange 



\section{3.}

the same thing is noticeable. According to observations I made at Glen St. Mary, Florida, and according to the men in charge, segregation appears to occur relative to the percentage of the leaves with three leaflets. The $F_{I}$ shows all leaves with three leaflets like Citrus trifoliata. With $\mathrm{F}_{2}$ and $\mathrm{F}_{3}$ however there are some types where leaves with three leaflets, leaves with two leaflets, leaves lobed on both sides, and leaves lobed on one side occur on the same tree. This appears to be the same phenomenon as with Malus, and gives support to the rating given M. floribunda and $M$. atrosanguinea as to their hybrid nature.

Pigmentation correlation appears in the red glands on the leaf and rich blood red fruit of Halus atrosanguinea. It is of interest that root cortex pigmentation correlates with flower color in red, Jellow and pink flowered carnations.

In twigs, as with the leaves, a more typical expression of the growth characteristics of a species is to be found near the center of a twig where growth is not stunted by side tracked nourishment, as at the base, nor obscured by luxuriance of nourishment and heavy pubescence as at the tip. The bark colors were taken from the same portion of the twig and standardized by the use of Robert Rịdgway's "Color Standards and Nomenclature". Drawings of buds were made from lateral buds, centrally located. The different drawings, however, of any one species, are not of the same node so that a leaf scar drawing and bud scale drawings are not always the same size as the same parts are on the bud drawings. The bud scales were dissected and removed in order from left to right to show the range of bud scale size and shape with the orig- 

inal growth sequence preserved. The measurements and discriptions dealing with bud shape refer to a front longisection view, unless otherwise indicated. 

5.

II. Key.

$* * *$

$\Lambda$ Key Based on Fall and Winter Characters of Some Species of Malus.

I. Leaves with lobes

A. Iobing constant throughout

1. Leaves strongly lobed i.e. lobing $30-60 \%$ in depth

a. Five to seven lobes in leaves; abortive branches spined; three out of five bud scales visible, leaves and twigs strongly pubescent

M. ioensis

b. Three to five lobes in leaves; abortive branches budded; five out of eight bud scales visible; twigs and leaves sparingly pubescent to glabrous

II- toringo

2. Leaves not strongly lobed i.e. lobing under $20-25 \%$ in depth

M. Soulardi

B. Lobing not constant throughout $1 . e$. present in less than $50 \%$ of leaves.

1. Buds acute, elongate ovate to lanceolate; six to seven out of eleven bud scales visible; leaf lobing very unsymmetrical and present in only 7 - 10\% of leaves; serration sinuses shallow (depth ratio $2.5 \%$ )

M. floribunda

2. Buds ovate acute, five to six out of eight bud scales visible; leaf lobing unsymmetrical but present in $17-20 \%$ of leaves; serration sinuses deep (depth ratio $8 \%$ ) 

II. Leaves without lobes.

A. Leaves strongly pubescent i.e. hairs persistent on surfaces of terminal fruit spur leaves

1. Branches decumbent, winter bud scales smothered with pubescence; two to three out of three bud scales visible

M. malus pendula

2. Branches erect, winter bud scales not smothered with pubescence; three out of four to six bud scales visible.

a. Serrations very irregular, rarely mucronate; lenticels round to lanceolate; leaf scars broad, crescent shaped, branching very erect and straight

I- astrachania

b. Serrations fairly regular, often mucronate; lenticels round; leaf scars narrow, crescent shaped; branching erect, very spreading

\section{II. ringo}

B. Leaves not strongly pubescent

1. Leaves serrate to biserrate; stipules persistent and strongly serrate to lobed; buas elongate ovate with ovate acuminate bud scales

a. Leaves ovate acuminate;petioles slightly pigmented with red; lenticels round to lanceolate; branching erect, straight to slightly spreading

1. Scheideckeri

b. Leaves ovate to elliptical acuminate; petioles and mid rib backs strongly pigmented with red; lenticels round to transverse elliptical; branching erect, very spreading

II. Arnoldiana 

2. Leaves serrate to dentate; stipules when persistent lanceolate to linear or reduced; buds ovate blunt or acute to elongate ovate acute with ovate blunt to acute bud scales. a. Only three bud scales showing

(I) Serrations very irregular, rarely mucronate, leaf scars broad, crescent shaped; branching very erect and straight.

M. astrachania

(2) Serrations fairly regular, often mucronate; leaf scars narrow, crescent shaped; branching erect, very spreading.

I. ringo

b. Usually five bud scales shoring

(1) Leaves elongate ovate acuminate

II. baccata

(2) Leaves elliptical to ovate and abruptly acuminate to acute

(a) Nargin irregularly serrate, apex 6 - $9 \mathrm{~mm}$; leaf scar broad, wedge shaped, buds ovate acute

I- Sargentii

(b) Margin irregularly dentate to serrate, apex 7 - $12 \mathrm{~mm}$, leafscar a broad crescent, buas ovate blunt to wedge shaped

II. sylvestris

3. Leaves denticulate to wavy margined, buds ovate blunt to acuminate, stipules linear to lanceolate except in

M. Halliana 

a. Stipules nearly deciduous, lanceolate to linear, freguently reduced when present, leaf scars crescent shaped; branching erect, straight to only slightly spreading (I) Leaves thin smooth backed, very symmetrical with a broad rounding base; elliptical acuminate to acute, only three out of five bud scales visible, buds ovate blunt; branching erect and straight.

\section{in. microcarpa}

(2) Leaves thin but not smooth backed and rather unsymmetrical, base rounding elliptical or ovate acuminate to acute; buds ovate acute with five out of eight bud scales showing: branching erect, slightly spreading.

$$
\text { M. dioica }
$$

b. Stipules persistent, falcate and strongly serrate to lobed; leaf scar broad wedge shaped; branching ereat, very spreading.

$$
\text { M. Halliana }
$$



Malus loensis Britt., Man. 516. 1901, Pyrus 1oensis Bail., Pyrus coronaria ioensis Wood.

Leaves in Fall:

Leaves 6 - $10 \mathrm{~cm} \cdot$, ovate blunt to mucronate with a broadly tapering base; 5 - 7 mucronate lobes with a $30-40 \%$ incut, 10 be sinus angle 90 - 110 degrees, lobes present in all leaves; margin mucronate, serrate to dentate; principal veins strongly impressed above and very prominent below, waving, and areolate along principal veins above; pubescence very dense on all lower surfaces, petioles red tinged; petiole 25 - $30 \mathrm{~mm} \cdot$, round, stout, with groove closed; stipules scarcely persistent, linear and pointed when present, with an entire margin; terminal fruit spur leaves elliptical mucronate with a broady tapering base, 3 - 5 lobes. Twigs in Winter:

Branching erect, somewhat spreading; bark dull liver brown, lenticels 30 - 35 per internode, usually lanceolate to linear; internodes about 18 per year's growth, markedly zigzagged, strongly keeled with side ridges prominent, pubescent at least on bud face sides for nearly half the year's growth; buds $2.5 \times 3.5-3 \times 4 \mathrm{~mm}$., ovate acute, flat to bulging on backs, appressed to spreading, ascew, apex and bud scale margins pubescent; bud scales elongate ovate, three out of five showing, rather definite lobe sinuses, smooth without prominent ridges; leaf scar crescent shaped with incurved margin and bundle scar incurves on upper margin, no subtending flange. 


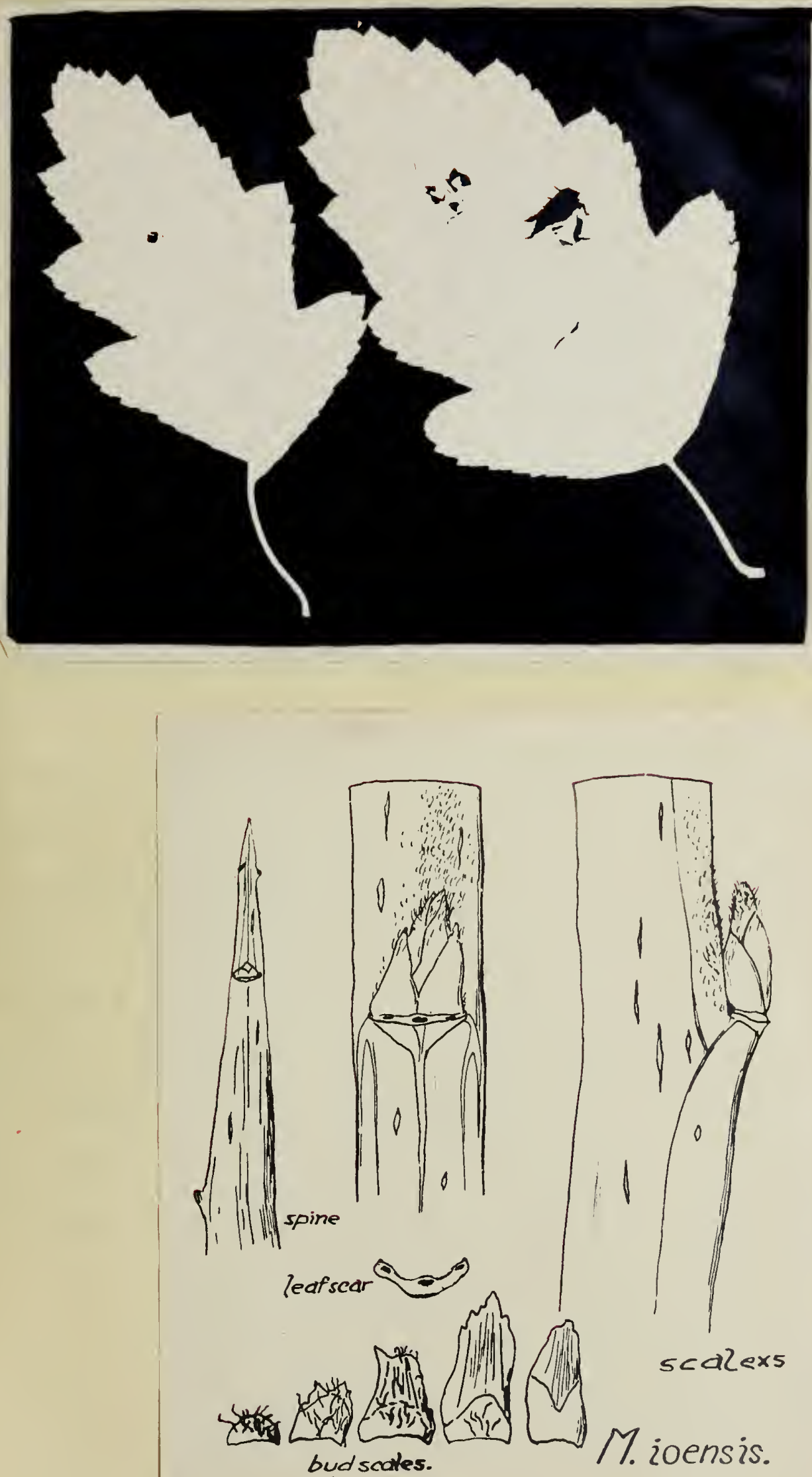

Malus toringo Sieb., Cat. rais. I. 4. 1856. Pyms toringo K. Koch. Leaves in fall:

Leaves $4-6 \mathrm{~cm}$, ovate acute with a rounding base; $3-5$ acute lobes with a 50 - $60 \%$ incut, lobe angle 50 - 70 degrees; margin deeply serrate almost to the petiole; principal veins strongly impressed above and prominent below, leaves waving to undulate, and twisted, upper surface minutely areolate at times; pubescence restricted mainly to the principal veins below, petiole red tinged; petioles 8 - $12 \mathrm{~mm}$,round somewhat terete with groove closed; stipules 7 - $9 \mathrm{~mm}$. , elongate ovate acuminate, spreading, recurved, serrate with basal notches; terminal fruit spur leaves elongate, ovate or elliptical with a tapering decurrent base, notched to lobed. Twigs in winter:

Branching bushy to scraggy and almost pendulous; maroon to diamine brown, lenticels round to elliptical 15 - 20 per internode; internodes 30 per year, somewhat zigzagged and keeled with side ridges rather prominent; buds $1.5 \times 1.5-2 \mathrm{~mm} \cdot$, short and bluntly ovate, flat backed, appressed to slightly spreading, glabrous; bud scales ovate acute with 5 out of 8 visible, pubescence restricted to tips of 7 and 8; leaf scar broad crescent shaped, not flanged. 


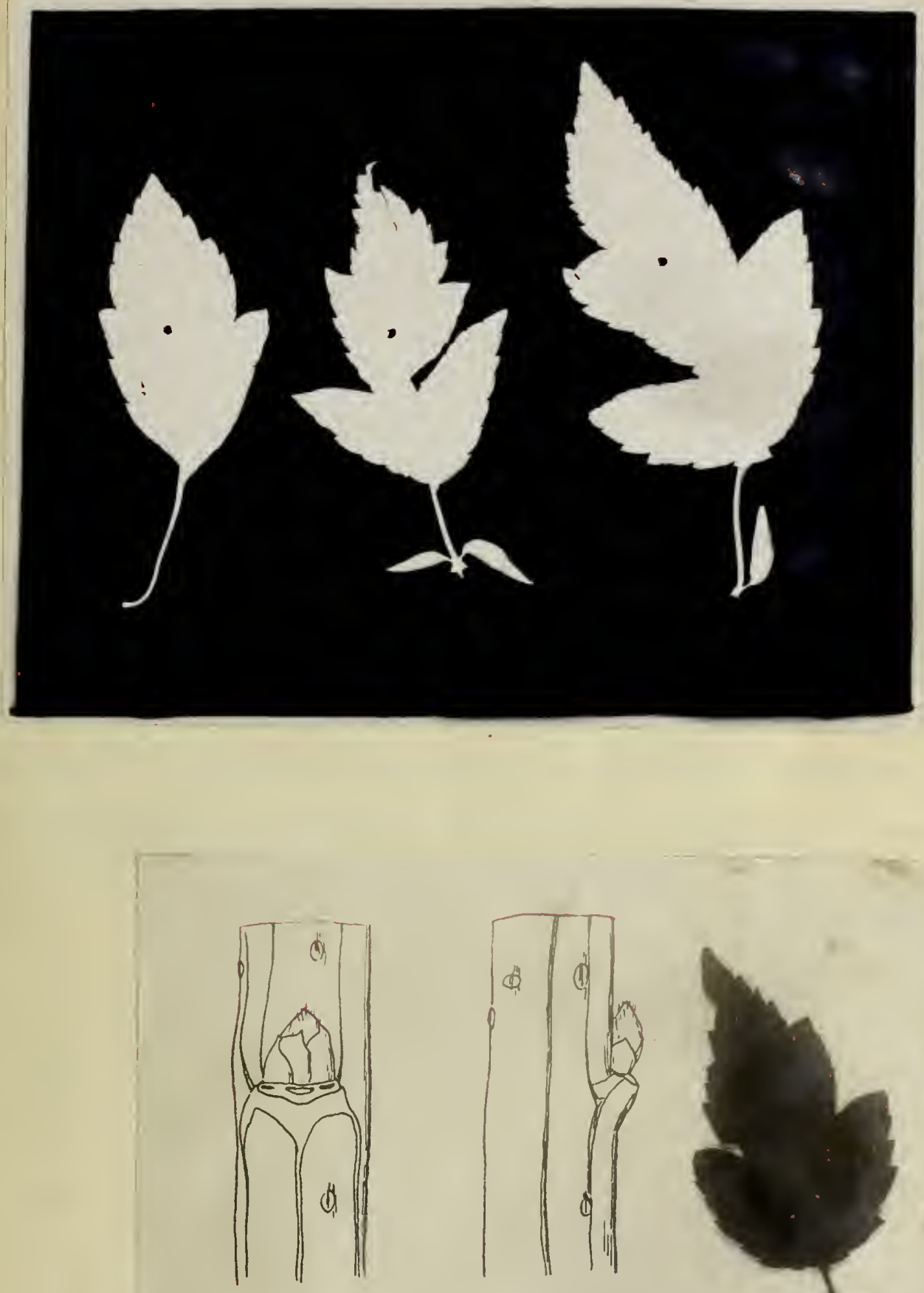

-0)

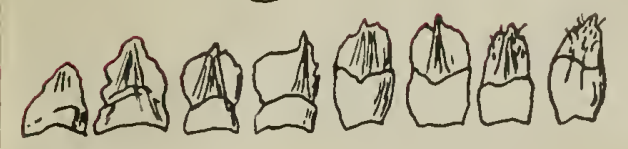

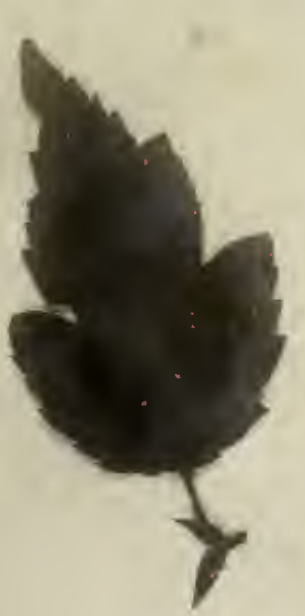



Malus Soulardi Britt., Man. 516. 1901.

Pyrus Soulardi Bailey.

Leaves in fall:

Leaves $5-8.5 \mathrm{~cm}$, ovate blunt to slightly mucronate with

a broad rounding somewhat cordate base; two to four mucronate lobes incut 15 - 25\%; margin mucronate dentate; principal veins deeply lmpressed above and prominent below, leaves undulate, deeply areolate above; strongly pubescent with hairs restricted to mid rib and petioles of fruit spur leaves, petiole $17-22 \mathrm{~mm} \cdot$, very stout, round with groove closed; stipules not persistent; terminal fruit spur leaves notched, elliptical, mucronate or blunt, mucronate serrate to dentate.

Trigs in winter:

Branching erect, somewhat spreading; bark burnt umber to black Van Dyke brown, lenticels $35-45$ per internode, round to elliptical becoming linear near end of twig; internodes $20-25$ per year, somewhat zigzagged, keeled, side ridges bulging just below bud but otherwise not prominent, strongly pubescent near end of twig with slight streaks near center above buds; buds 2.5 $2.5-2.7 \times 2.8 \mathrm{~mm} \cdot$, ovate acute, flat, appressed, straight, very pubescent with bud scale surface exposed only at the base; bud scales ovate acute to blunt with 4 out of 5 showing, smooth and not ridged; leaf scar narrowly crescent shaped, bundle scar incurves lacking, strongly flanged. 


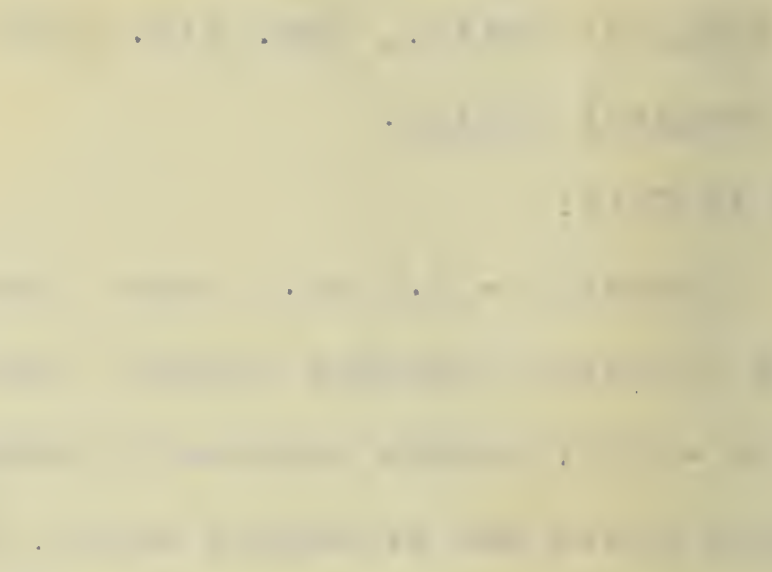

1 n

, 

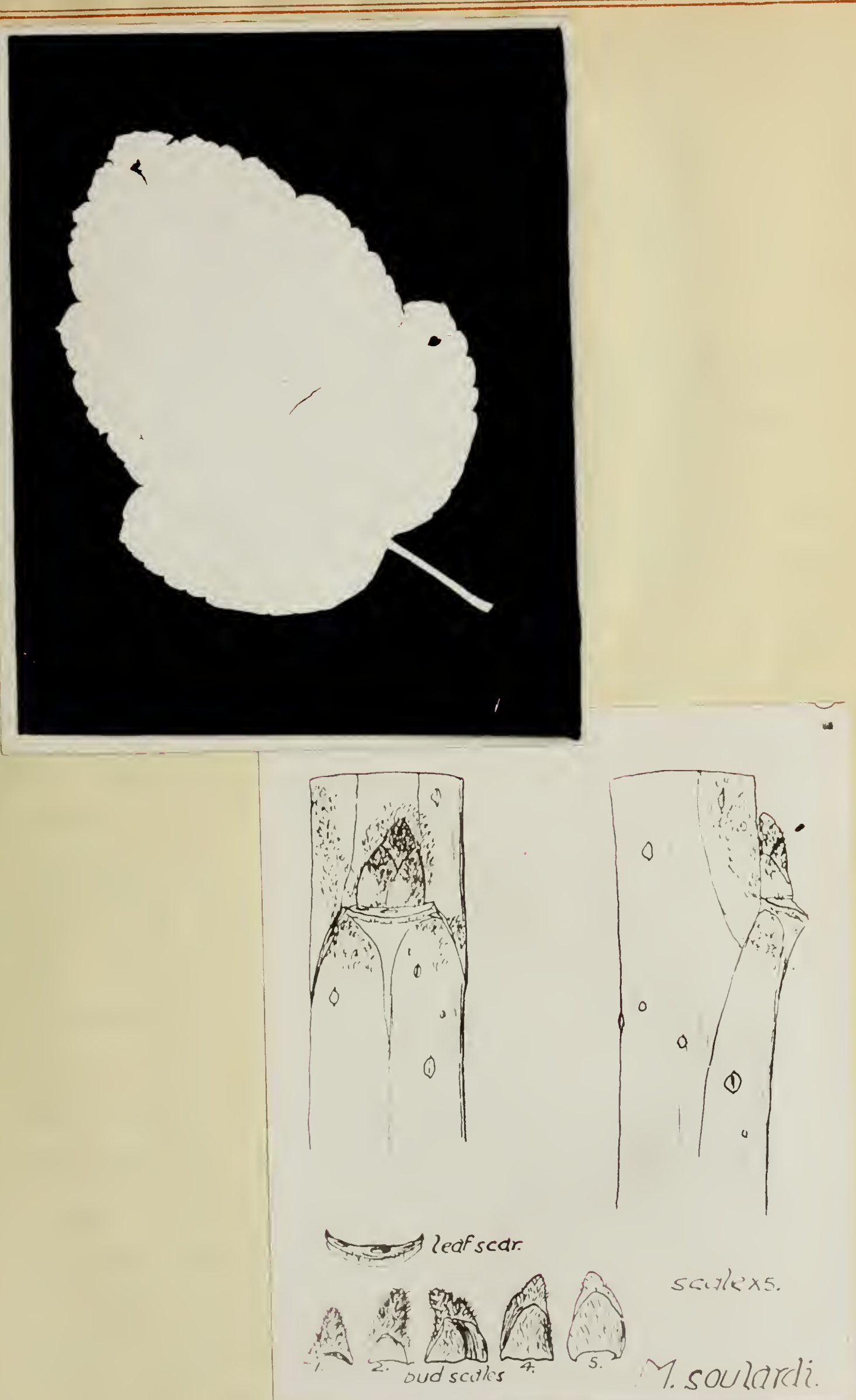

Malus Iloribunda Sieb., in Fl.d.Serr. XV $1862-65$

Malus microcarpa floribunda Carr. Pyrus floribunda Voss

in Vilm. Blumeng. 3 Aufl. 277. 1896

Leaves in fall:

Leaves $4.5-7 \mathrm{~cm} \cdot$, ovate acuminate; under $10 \%$ of leaves very unsymmetrically lobed with an incut of $30-40 \%$, fruit spur leaves not lobed; margin mucronate serrate with an incut of $2.5 \%$; principal veins somewhat impressed above, rather outstanding below and leaf surfaces smooth to waving and slightly areolate; glabrous, petioles and mid rib backs tinged with red; petiole $10-18 \mathrm{~mm}$., terete with groove open; stipules 9 - $15 \mathrm{~mm} \cdot$, persistent, falcate acuminate, notched or lobed at the base, spreading, serrate to entire; terminal fruit spur leaves lanceolate, serrulate, not lobea. Twigs in winter:

Branching erect, very spreading; glossy aniline black, lenticels 30 - 35 per internode mostly round to somewhat elliptical; internodes 30 - 50 per year, somewhat zigzagged, keeled, side ridges not prominent, glabrous except 'neath bud faces near the tip and for terminal internode; buds $2.2 \times 3-2.5 \times 4 \mathrm{~mm} \cdot$, elongate ovate to ovate acuminate, flat to rounding or bulging, spreading or not closely appressed, ascew, fringed and slightly tipped with hairs; bud scales broadly ovate acute to ovate acute with seven out of eleven bud scales showing, strongly ridged; glabrous except for fringe on lower scales and tip of upper scales; leaf scars broady crescent to wedge shaped with slight incurve above and side bundle scar incurves below, distinctly flanged. 


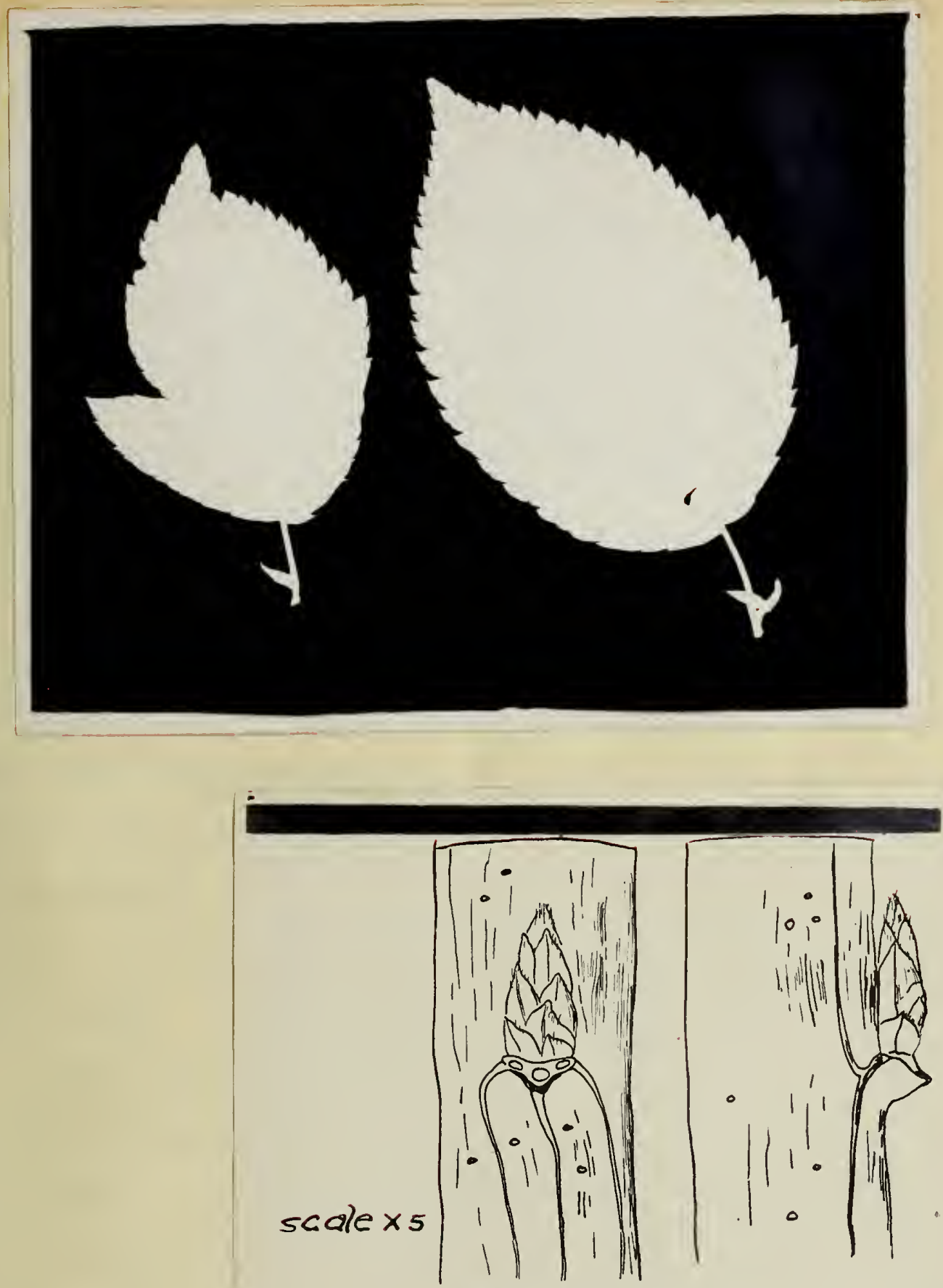

ogl leafscar.

Y. floribundo.

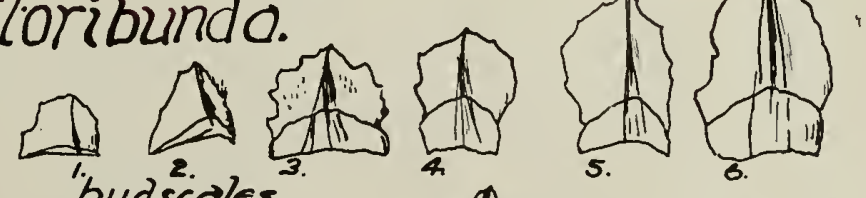
budscales.

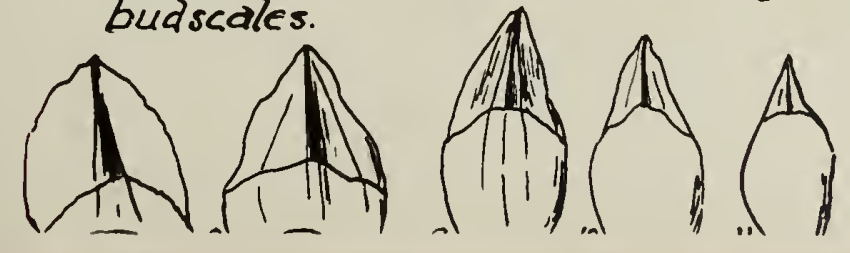



lialus (Pyr.) atrosanguinea Hort. Spath, Cat. $1905-6$ Pyrus floribunda var. atrosangumia ? Leaves in fall:

Leaves $5-7.5 \mathrm{~cm} \cdot$, ovate acute rounding at the base; $12-16 \%$ of leaves unsymmetrically three lobed with an incut of $40-60 \%$, lobes blunt to slightly mucronate; margin deeply serrate (8\%); principal veins somewhat impressed to flush above, rather outstanding below, leaf surfaces smooth to waving and slightly areolate; pubescence persistent on mid rib backs and petioles of fruit spur leaves, leaf surfaces nerrly glabrous, petioles and mid rib backs red tinged; petioles $1.5-2 \mathrm{~cm}$. , terete with groove open; stipules 8 - $12 \mathrm{~mm} \cdot$, ovate acuminate, spreading, serrate with outer basal lobe present; terminal fruit spur leaves lanceolate to elongate elliptical, serrulate to almost wavy margined. Twigs in winter:

Erect, very spreading; bark glossy, claret brown to black claret brown, lenticels 25 - 30 per internode, round to transverse18 elliptical; internodes 28 - 34 per year, somewhat zigzagged, keeled, side ridges not prominent, glabrous except behind buds and near terminal node; buds $2.5 \times 3-2.5 \mathrm{~mm}$, ovate acute, flat to bulging, spreading to not closely appressed, somewhat ascew, apez, and margim of scales hairy; bud scales ovate acute with 4 - 5 out of 8 showing, fringed and rather strongly tipped with hairs; leaf scars broadly crescent shaped with side bundle scar incurvesprominent below, flanged. 


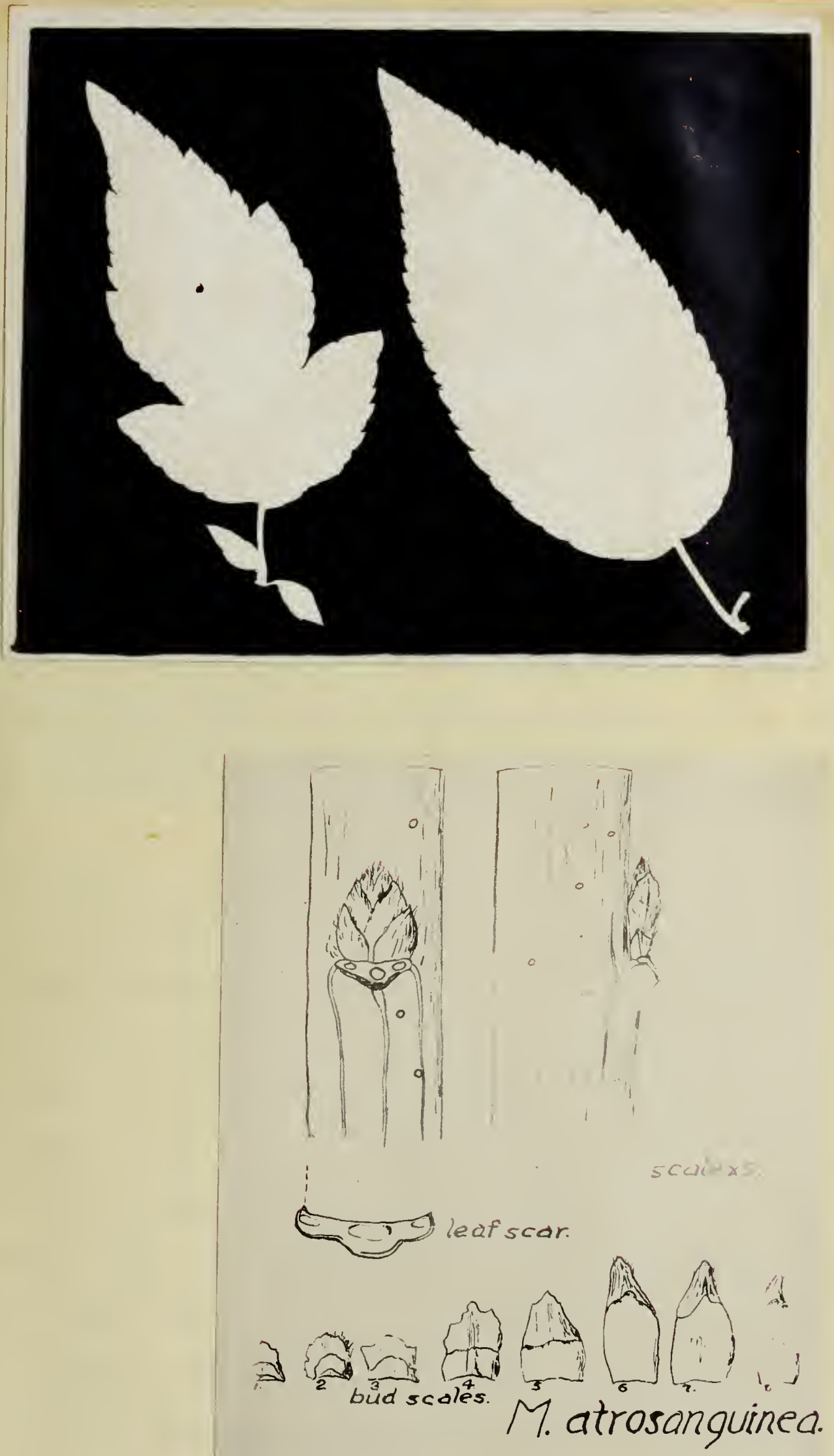

$5 c \cos x$ 

M. malus pendulus

Leaves in fall:

Leaves $6.5-8 \mathrm{~cm} \cdot$, asymmetrical, ovate or elongate ovate to elliptical, acuminate with a rounaing base; margin irregularly serrate; principal veins flush to somewhat impressed above and prominent below, leaves smooth to waving and slightly areolate along principal veins; pubescence persistent on leaf surface of all leaves, petioles tinged with red; petiole $25-33 \mathrm{~mm} \cdot$, stout, round with closed groove; stipules $10-14 \mathrm{~mm}$. , reduced and awl shapea or elongate obovate to lanceolate, spreading and recurved, margin entire; terminal fruit spur leaves elongate obovate or elliptical acuminate, irregularly and sharply serrate, base tapering to broady tapering.

Twigs in winter:

Branching decumbent to trailing; bark dull to slightly glossy, between chocolate and warm, blackish brown, lenticels 25 - 30 per internode, mostly round to elliptical, at times elongate elliptical to lanceolate; internodes 20 - 30 per year, not zigzagged, whole twigs sway backed indicating a pendulous nature, very pubescent on upper half of twig with streaks of strong pubescence above the lower buds; buds $2.5 \times 2.5-2.7 \times 2.8 \mathrm{~mm} \cdot$, bluntly ovate acute, flat, not keeled, side ridges strongly bulging just below the bud but otherwise not prominent, appressed, straight, "smothered" with pubescence; bud scales bluntly ovate with three out of three scales showing, not ridged, smothered with pubescence; leaf scar crescent shaped or with prominent side scar incurves on upper margin, flanged. 


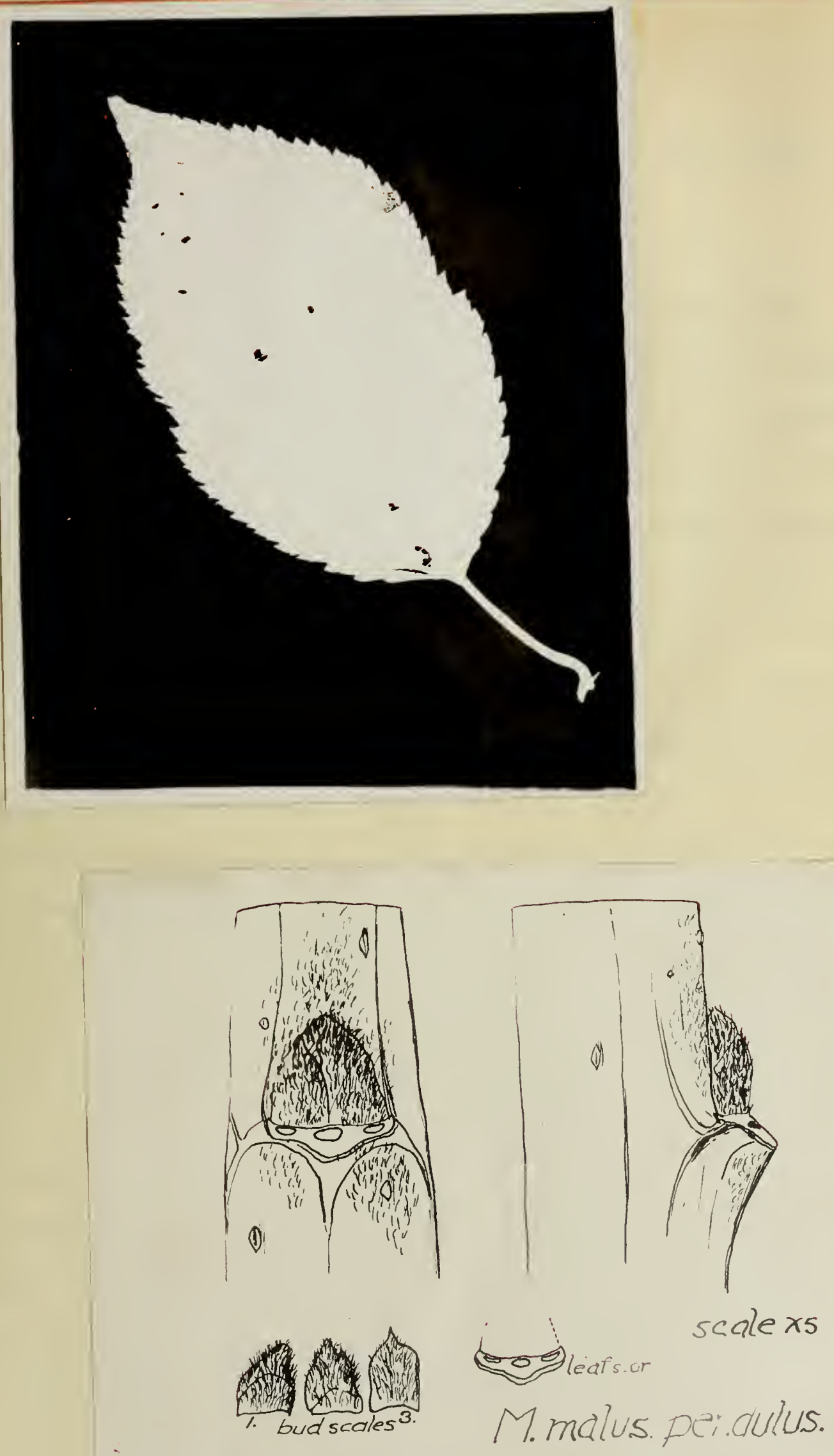

Malus astrachania Dum. Cours., Bot. ed.2. V. 429. 1811 Pyrus astrachania, DC., Prodr. II 635.1825

Leaves in fall:

Leaves $6.5-8 \mathrm{~cm} \cdot$, broady ovate or elliptical and abruptly acuminate, asymmetrical, with a broadly rounding base; irregularly serrate; principal veins slightly sunken to slightly raised, prominent below, upper surface areolate; pubescence persistent at least on lower surfaces of vegetative leaves, petioles red tinged; petioles $2.5-3 \mathrm{~cm}$, terete, rather stout, groove well marked but rather shallow; stipules $4-5 \mathrm{~mm}$, reduced, awl shaped, spreading; terminal fruit spur leaves elliptical with a rounding base to obovate with a slightly tapering base, irregularly serrate to serrulate.

Twigs in winter:

Branching very erect and straight; bark chocolate red brown, lenticels 20 - 30 per internode, circular to elongate elliptical; internodes 20 - 30 per year, straight and not zigzagged, keeled, side ridge bulging just below the bud and somewhat outstanding below, first 3 or 4 internodes and bud sides of upper internodes very pubescent; buds $2.3 \times 2.7-2.7 \times 3.0 \mathrm{~mm} \cdot$, bluntly ovate or wedge shaped, distinctly appressed, straight, flattened to somewhat rounding on backs, upper half of buds pubescent; bud scales ovate acute with 3 out of 6 showing, somewhat ridged, almost glabrous; leaf scars broadly crescent shaped, heavily flanged, almost obscured by hairs at base of bud. 


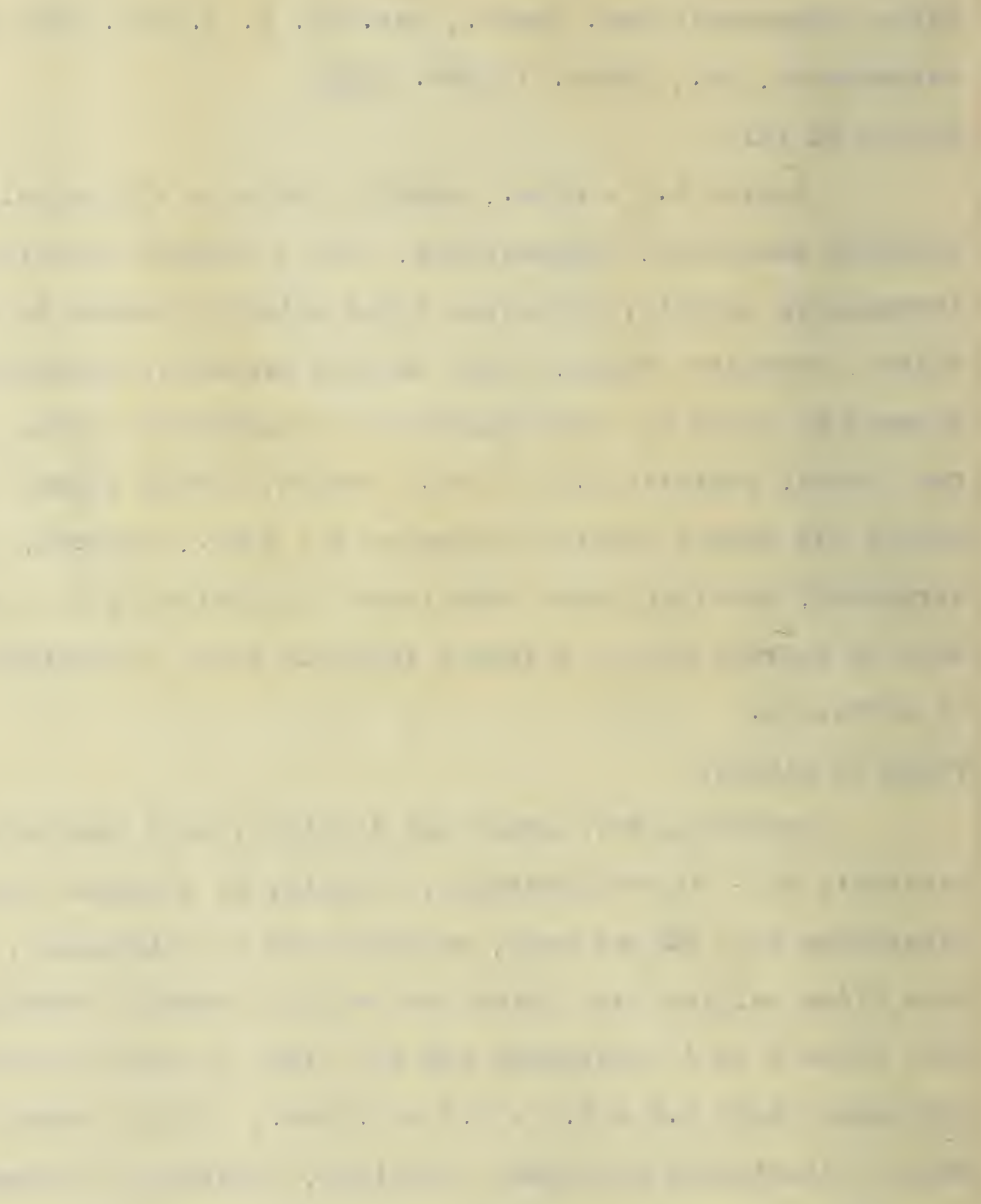



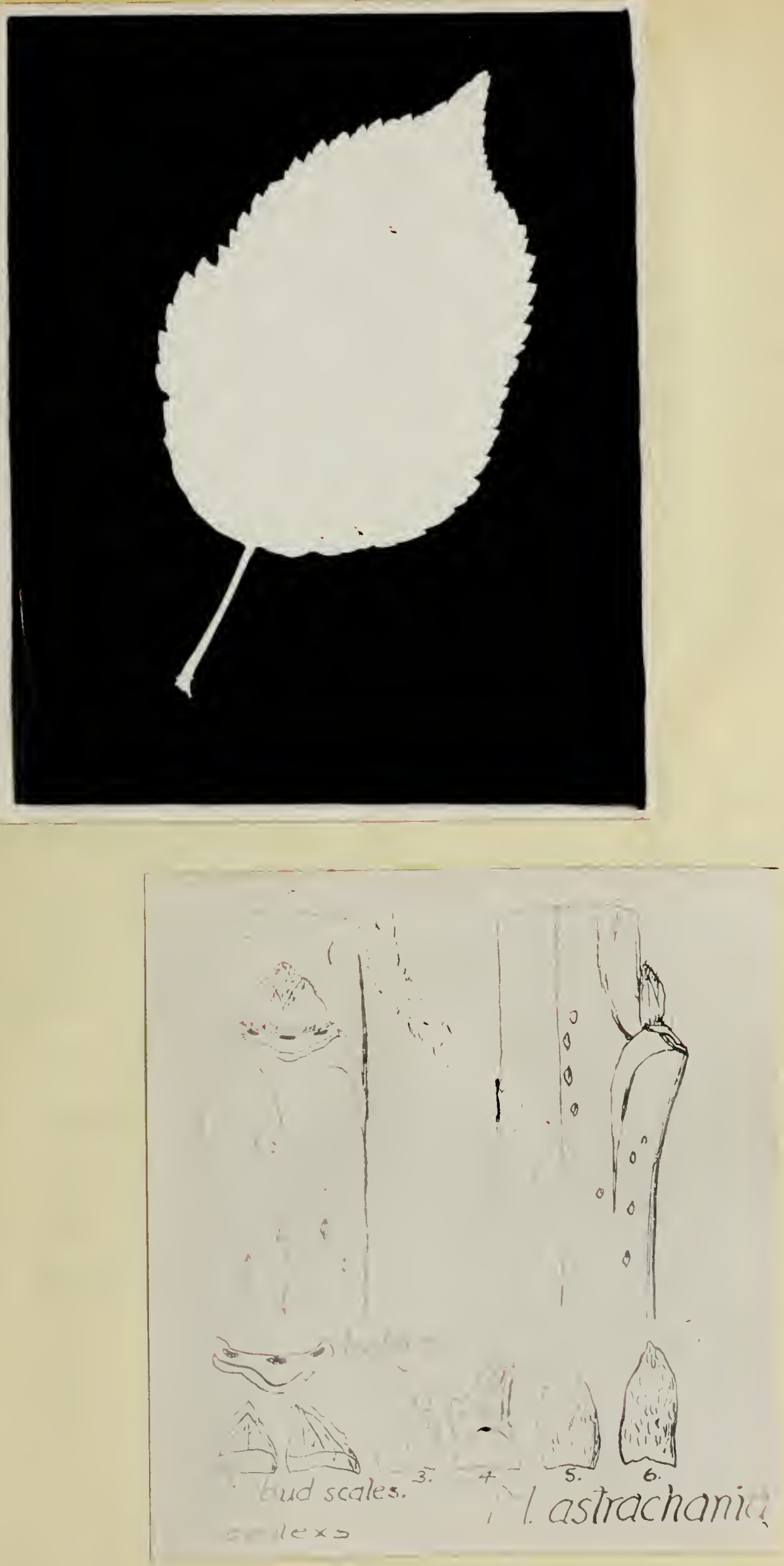

Malus ringo sieb., Cat rais. 5.1856.

Leaves in fall:

Leaves 4 - $7 \mathrm{~cm} \cdot$, elliptical acuminate with a rounding base; rather evenly serrate; principal veins impressed above, prominent below, upper surface areolate; pubescence persistent on surface of all leaves, moderate density, petioles and part of mid rib backs red tinged; petioles 12 - $22 \mathrm{~mm} \cdot$, terete with groove open; stipules 6 - $8 \mathrm{~mm} \cdot$, lanceolate, entire, at times with outer basal lobe; terminal fruit spur leaves elliptical acuminate with a rounding to broady tapering base, serrate to denticulate.

Twigs in winter:

Branching erect and very spreading; bark glossy, claret brown, lenticels 20 - 25 per internode, round; internodes $16-21$ per jear, zigzagged, keeled with side ridges not bulging just below the bud but rather outstanding below, sparingly pubescent near tip and 'neath buds along terminal internodes; buds $1.8 \times 2.0-2.3 \times 2.5$ mm., blunt, ovate and wedge shaped, appressed to slightly spreading, straight, very flat and straight backed, glabruos only at base of outer scales; bud scales bluntly ovate to wedge shaped, not ridged, pubescent except at bases; leaf scar crescent shaped, flanged. 


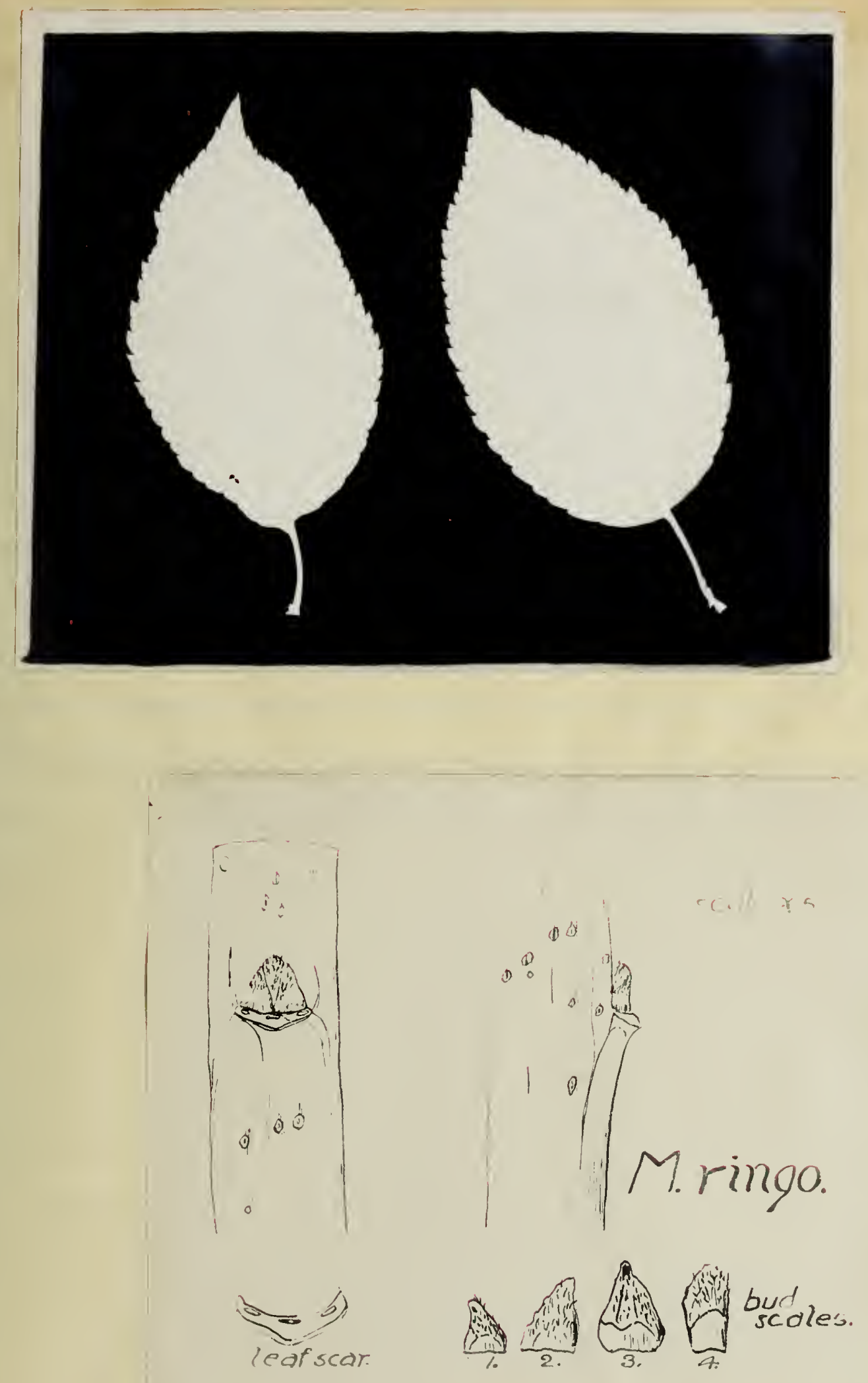

Malus Scheideckeri Zbl., H.d. D.D.G. 188. 1903 Pyrus Scheideckeri Leaves in fall:

Splth, Cat. 1888 .

Leaves $4.5-6 \mathrm{~cm} \cdot$, long, ovate acuminate with a rounding base; regularly diserrate, incut $8 \%$, tips of teeth mucronate to bluntly mucronate, teeth extending to within $.5 \mathrm{~cm}$., of the petiole; principal veins almost flush to raised not prominent below, upper surface wrinkled and smooth, minutely areolate at times; pubescence lacking except on petioles of all leaves, petioles tinged with red; petioles $12-15 \mathrm{~mm}$, terete, of medium thiclmess, with a deep open groove; stipules $7-12 \mathrm{~mm} \cdot$, persistent, foliacious, ovate to lanceolate, strongly serrate vith an outer basal lobe, somewhat spreading and recurved; terminal fruit spur leaves ovate with a rounding base to elliptical or lanceolate, serrulate to biserrulate. Twigs in winter:

Branching erect, straight to slightly spreading; bark dull, claret brown to maroon, lenticels 25 - 30 per internode, round or elliptical, at times linear near end of twigs; internode $37-47$ per year, not zigzagged, not ridged, pubescent near tips and behind buds; buds $2.4 \times 2.5-2.6 \times 3.2 \mathrm{~mm} \cdot$, blunt, elongate ovate to ovate, bulging, spreading and distinctly ascew, apex and bud scale margins pubescent; bud scales ovate acuminate with $4-5$ out of 8 showing, ridged distinctly, 1 and 2 iringed with hairs, 6,7 , and 8 hairy on upper half; leaf scar crescent to broadly crescent shaped with lower margin incurves, flanged. 


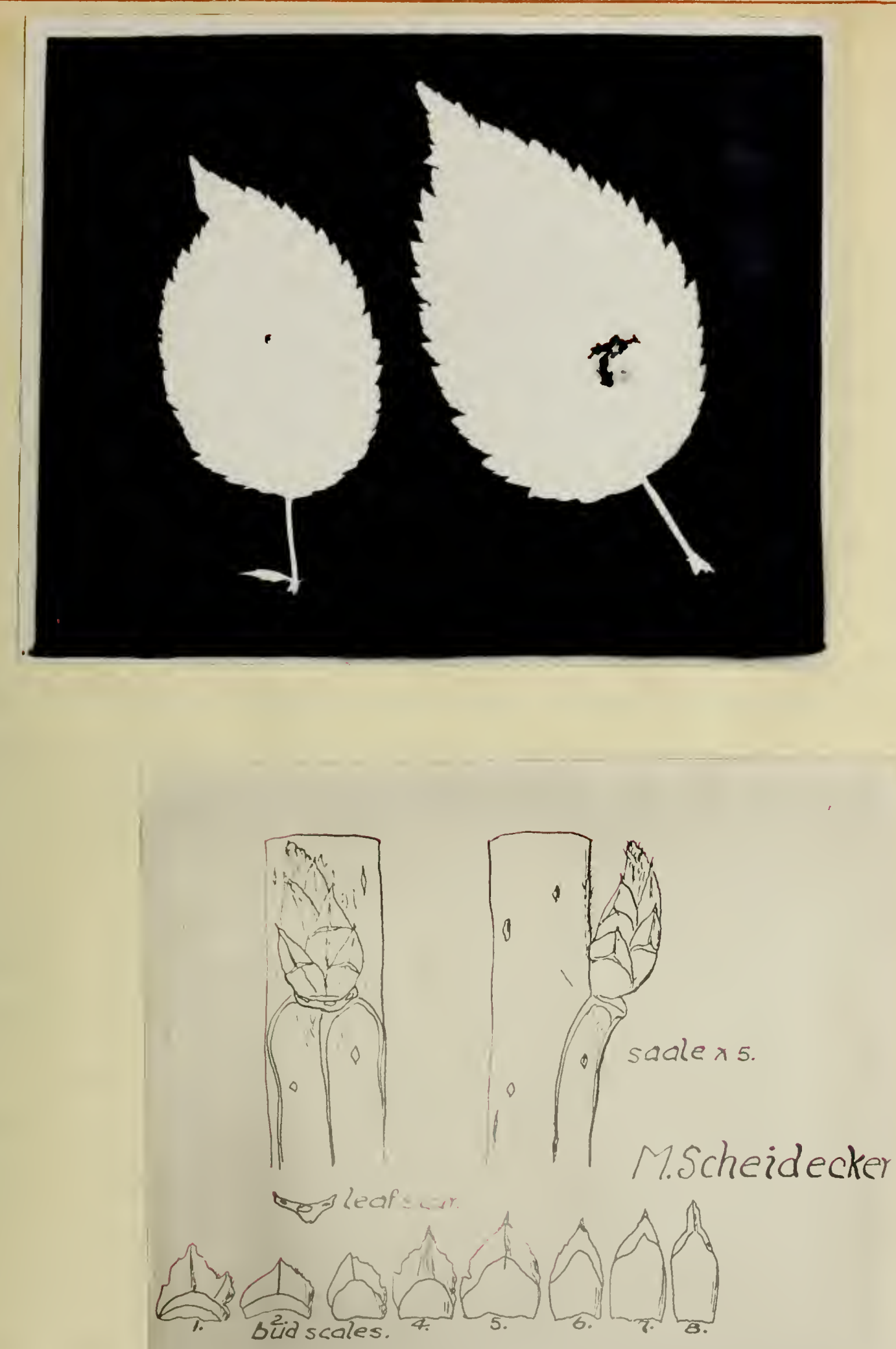

Malus Arnoldiana.

Leaves in fall:

Leaves $5-8 \mathrm{~cm} \cdot$, ovate to elliptical acuminate with a rounding base; regularly biserrate to serrate, tips of teeth usually acute, incut 5 - 12\%; principal veins flush above, not prominent below, leaf surface wrinkled and slightly areolate above near principal veins; glabrous,petioles and mid rib backs pigmented with red; petioles 15 - $25 \mathrm{~mm}$, terete, medium thickness, groove deep and spreading; stipules $10-12 \mathrm{~mm}$, broadly lanceolate to lanceolate with several dentate notches and strong outer basal lobes, erect to somewhat spreading, slightly recurved; terminal fruit spur leaves lanceolate serrate, at times with dentations near apex. Twigs in winter:

Branching erect, very spreading, bark claret brown, lenticels 20 - 25 per internode, short elliptical to round or even transverse elliptical; internodes 38 - 40 per year, somewhat zigzagged, somewhat keeled and ridged with side ridges not bulging just below bud, glabrous except for a very scant pubescence behind buds near ends of twigs; buds $2.0 \times 4.0-2.8 \times 5.0 \mathrm{~mm} \cdot$, elongate ovate to ovate acuminate, rounding to bulging, spreading, distinctly ascew, glabrous except for fringe of hairs on bud apex and bud scale margins; bud scales ovate acuminate with 5 out of 7 showing, ridged distinctly, pubescence restricted to fringes on the apical margins of 1 and 2 and apical ends of 6 and 7 ; leaf scar broaly wedge shaped to wedge shaped, margin not prominently inourved, not flanged. 



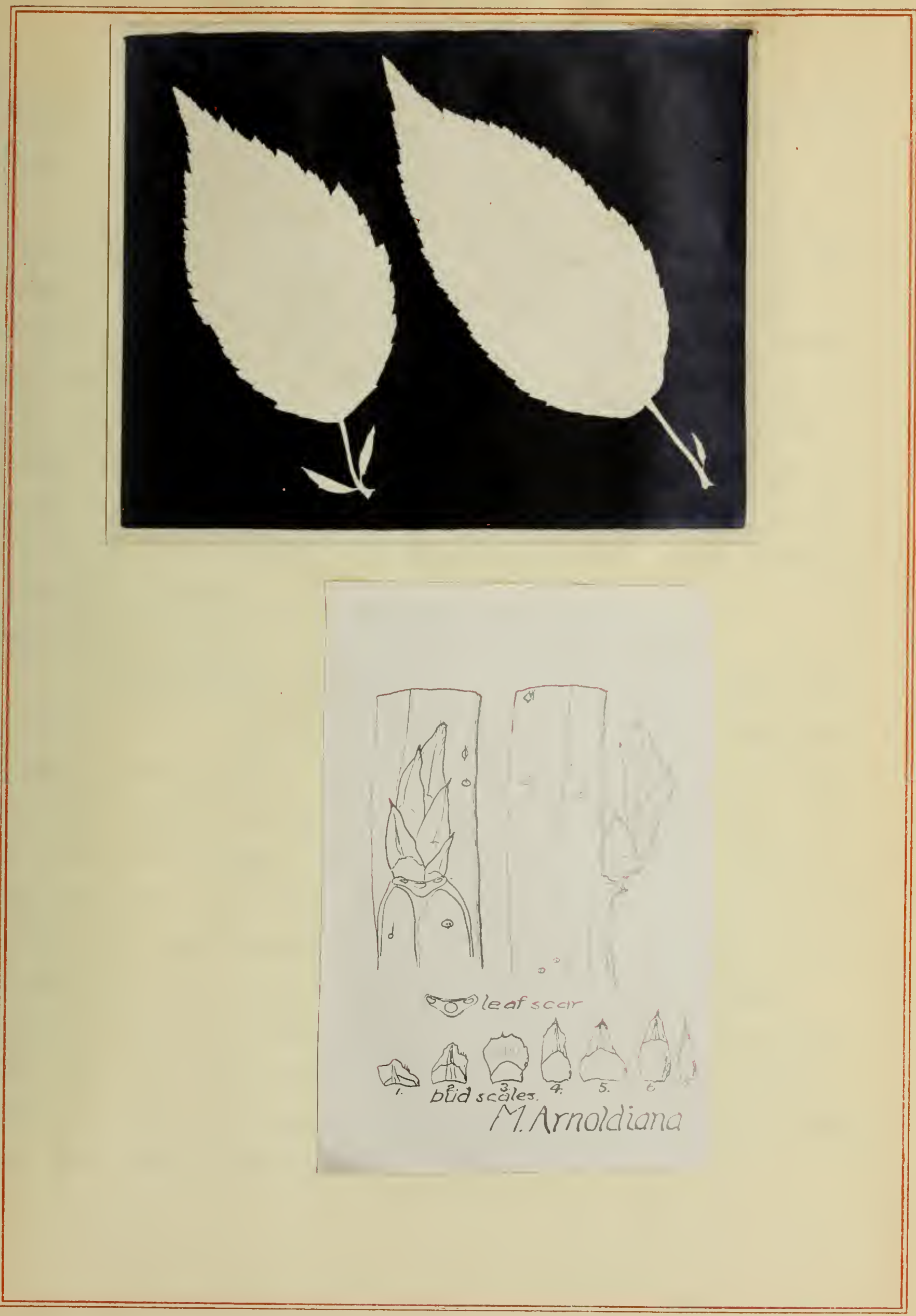



Malus baccata Borkh. Handb. Forstb. II. 1280. 1803 , Pyrus baccata I. Leaves in fall:

Leaves $6-9 \mathrm{~cm} \cdot$, elliptical, acuminate to acute, with a rounding base; irregularly serrate to crenate serrate; incut $4 \%$, rarely notched twice on terminal leaves, apex set off by deeper sinuses at the apex base; veins impressed above, prominent below, leaf surfaces wrinkled, slightly areolate and minutely areolate to a certain extent; glabrous except with terminal leaves, petioles tinged with red at base; petioles $20-30 \mathrm{~mm} \cdot$, round to terete, of medium thickness, groove partly open; stipules $5-7 \mathrm{~mm} \cdot$, scarcely persistent, linear, appressed; terminal fruit spur leaves elongate elliptical acuminate to acute, rather evenly errate. Twigs in winter:

Branching very erect and straight lmost of varieties are erect and straight and have ovate acuminate leaves); bark dull to slightly glossy, carb brown to argus brown, lenticels $35-40$ per Internode, round to elliptical to lanceolate; internodes $34-38$ per year, not zigzagged, keeled with side ridges bulging somewhat just below the bud, outstanding below, pubescent only in several bud notches just below terminal bud; buds $3 \times 4.5-3 \times 5.5 \mathrm{~mm}$. acute, elongate ovate to ovate, distinctly bulging, spreading, ascew, glabrous except for scant pubescence on tip end; bud scales ovate acute with five out of five showing, strongly ridged and flanged, pubescence scant on upper margins of 4 and 5 ; leaf scar wedge shaped with bundle scar incurves, strongly flanged. 


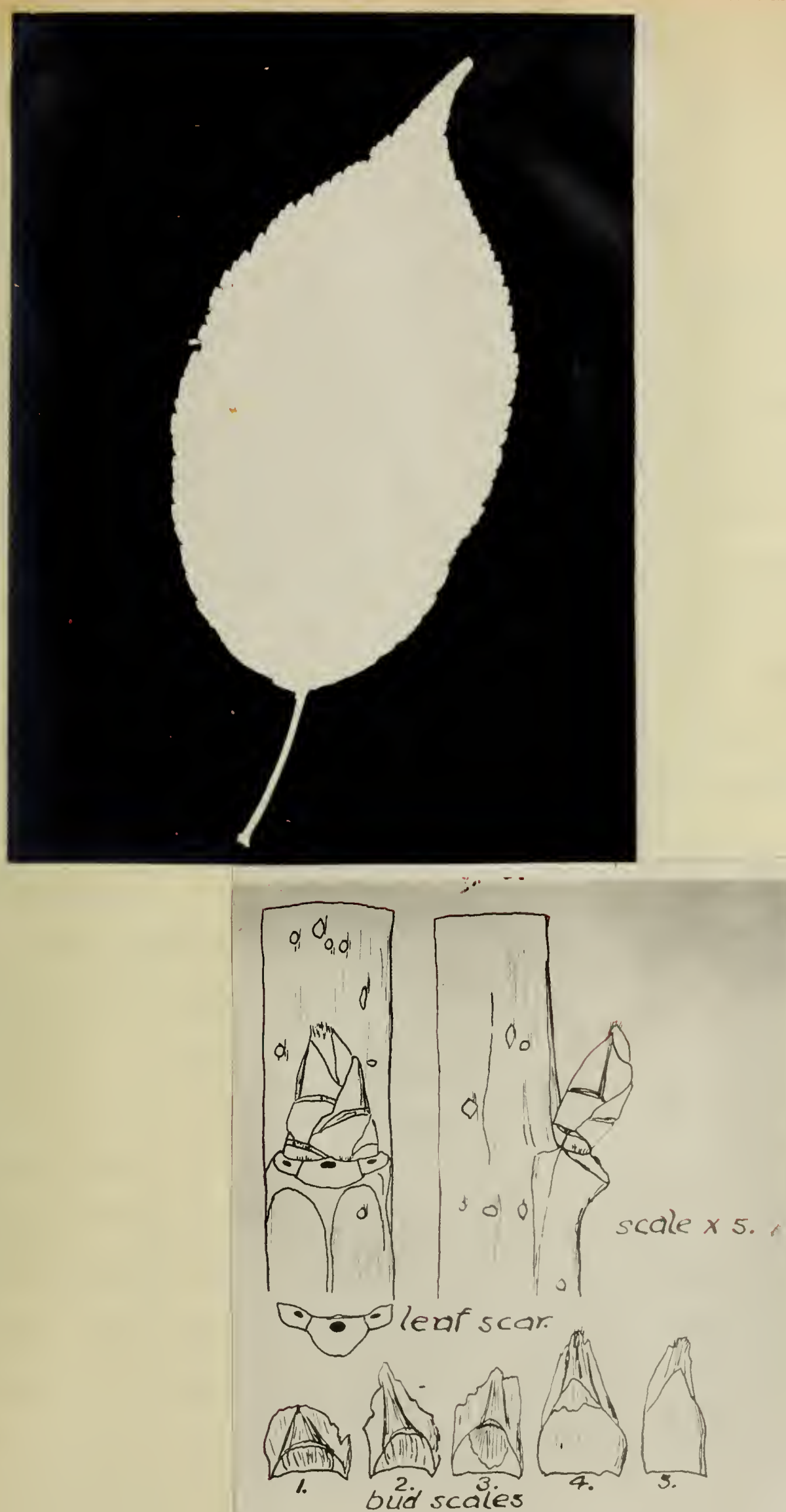

$$
\text { M. baccata. }
$$



Malus sylvestris. Schneider Handb. der Laubholzkunde

V. II 1906, Malus malus sylvestris Mill.

Leaves in fall:

Leaves $5-8 \mathrm{~cm} \bullet$, broadly elliptical abruptly acuminate with a broady rounding base; regularly dentate to serrate, with bottom of base only wavy margined or denticulate to entire, apex often set off by basal sinuses, inner side of teeth bulging, sinuses often 90 degree angled; principal veins impressed above, prominent below, leafs areolate and somewhat wrinkled above; sparingly pubescent on leaf surfaces, petioles slightly tinged with red; petioles 15 - $28 \mathrm{~mm} \bullet$, round, stout, groove closed; stipules 5 - $9 \mathrm{~mm}$. persistent only on terminal leaves, lanceolate entire, erect to somewhat spreading, incurved; terminal fruit spur leaves elliptical acuminate to acute, evenly serrulate to denticulate. Twigs in winter:

Branching erect, very spreading, bark claret brown to liver brown, lenticels short elliptical ( 35 - 45 per internode); internodes 25 - 41 per jear, somewhat zigzagged, not keeled or ridged, pubescent on upper $6-8$ internodes, below this a few streaks above buds; buds $2.5 \times 3.5-3 \times 4 \mathrm{~mm}$, ovate acute, thick and rounding to slightly bulging, appressed to slightly spreading, straight, strongly pubescent except for glabrous basal spots on lower scales; bud scales ovate acute with 5 out of 7 showing, strongly ridged and flanged, strongly pubescent except for glabrous basal spots on lower scale; leaf scar broad erescent to wedge shaped, upper margin only gently incurved, strongly flanged. 



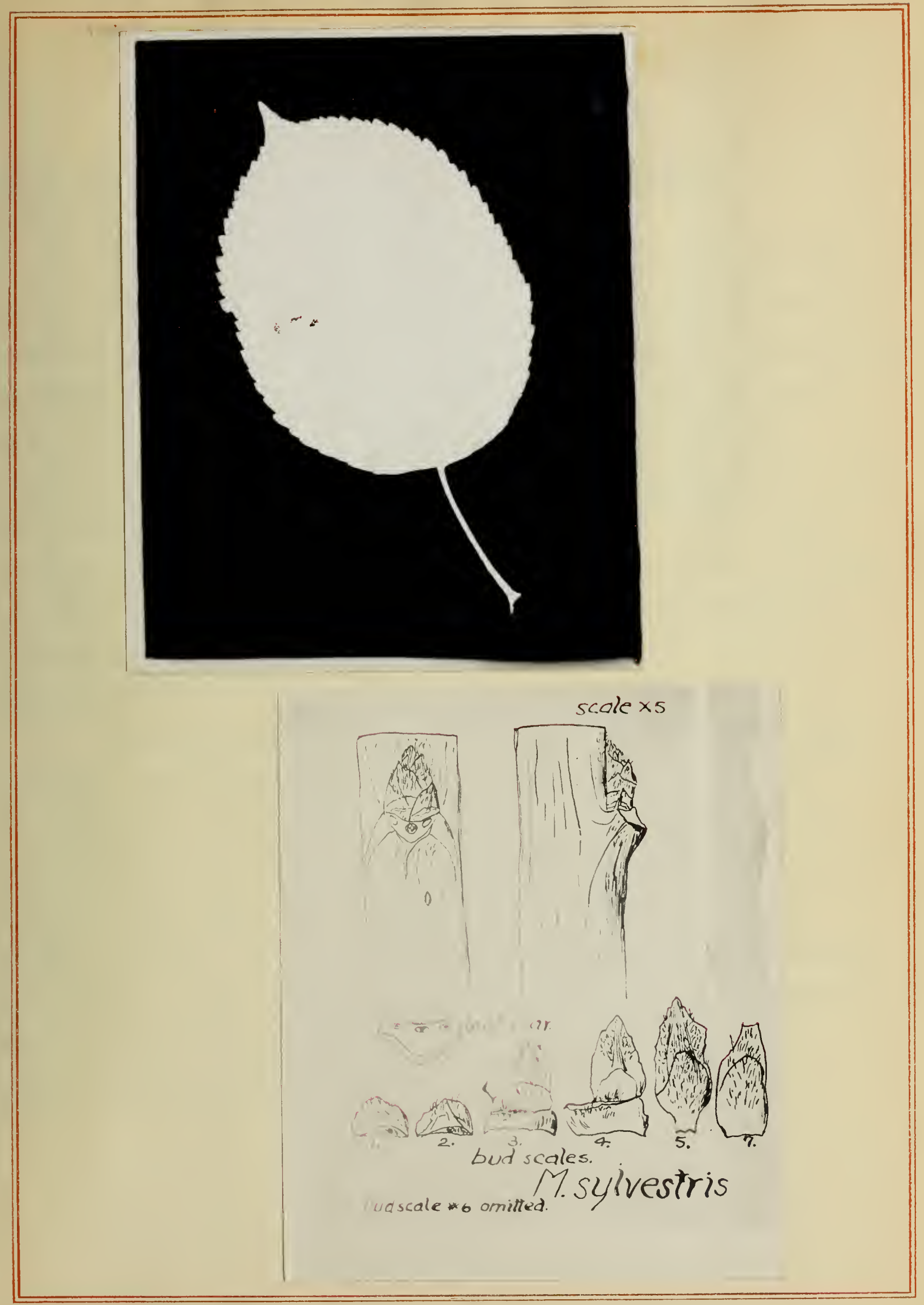



Malus Sargentii Rehd. Sargent's Trees and shrubs. 1903. Leaves in fall:

Leaves $4.5-6 \mathrm{~cm} \cdot$, broady elliptical to ovate acuminate with a rounding base; lobing rare and on terminal leaves if present; somewhat irregularly serrate, inner side of teeth nearly straight,rareIy with 90 degree angled sinuses; principal veins impressed above not prominent below, upper leaf surface areolate and wrinkled; almost glabrous, petioles slightly tinged with red; petioles 14 - 24 mm., round, stout, with groove closed; stipules 8 - $12 \mathrm{~mm} \cdot$, only persistent on terminal leaves, lanceolate entire somewhat spreading and incurved, strongly petiolate; terminal fruit spur leaves, elliptical acute to acuminate, evenly serrate. Twigs in winter:

Branching (low, intricate branched shrub) erect spreading: bark dull claret brown, lenticels 25 - 30 per internode, round; internodes 36 - 42 per year, straight, upper half pubescent, lower half pubescent near buds, not ridged or keeled; buds $2.5 \times 3-2.6 \mathrm{x}$ 3.2., thick and flat, ovate blunt, straight, apex and bud scale margin pubescent; bud scales ovate blunt with $4-5$ out of 6 showing, not strongly ridged or flanged, apex and bud scale margins pubescent; leaf scar narrow crescent shaped to crescent shaped, sometimes obocured by bud pubescence, flanged. 


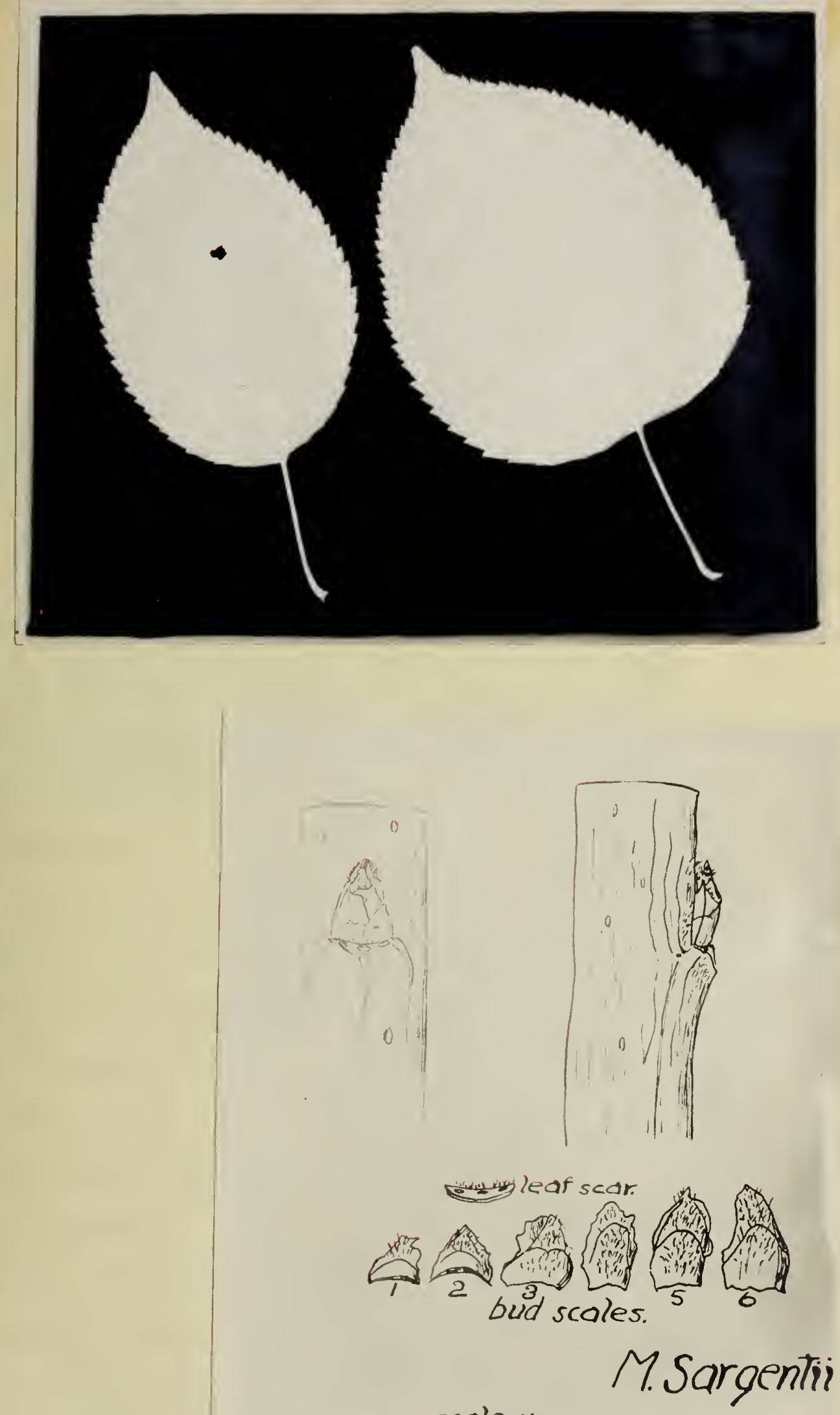

scole $\times 5$ 

Malus microcarpa Hort.

Pyrus microcarpa,

Leaves in fall:

D. C. Prod. ii 636

Leaves $4-7 \mathrm{~cm} \cdot$, elliptical to ovate acuminate, usually with a broady and symmetrically rounding base; margin entire to wavy or sparingly denticulate with sinuses at base of apex, and at times one or two prominent dentations; veins flushed to raised above, not prominent below, leaf surface smooth especially below, not areolate or wrinkled; glabrous, without glands, petioles red tinged; petioles $30-37 \mathrm{~mm}$, terete, slender, groove wide open, shallow; stipules 5 - $8 \mathrm{~mm}$, scarcely at all persistent, linear, entire, erect, incurved, not petiolate; terminal fruit spur leaves elliptical acute to slightly acuminate, base rounding to somewhat tapering, margin entire to serrulate.

Twigs in winter:

Branching erect, straight; bark slightly glossy, liver brown, lenticels 20 - 25 per internode, round to short elliptical; internodes $43-44$ per year almost straight, pubescent above, somewhat keeled and ridged with side ridges bulging just below bud on upper half of tw1gs; buds $2 \times 3-2.5 \times 3.5 \mathrm{~mm} \cdot$, blunt, elongate ovate to elliptical, medium thickness, flat to rounding or slightly bulging, stralght, appressed, very pubescent except for glabrous spots on lower scales, pubescent along upper margin of leaf scar; bud scales ovate acute to blunt with $2-3$ out of 5 showing, not ridged or flanged, pubescent except for glabrous spots at base of outer scales; leaf scar crescent shaped with bundle scar incurves, flanged. 


Malus dioica Audib. cat. $\nabla \cdot v \cdot$

Pyrus dioica Villa. arb. 263 spec. 5 p. 1018.

Leaves in fall:

Leaves 4 - $7 \mathrm{~cm} \cdot$, unsymmetrical, ovate to elliptical, acuminate with a rounding base; irregularly serrate to serrulate or crenulate, margin almost entire near petiole; principal veins not quite flush to slightly raised above, not prominent below, leaf surfaces slightly wrinkled, somewhat minutely areolate; almost glabrous with hairs persistent only on petioles, petioles red tinged; petioles 15 - $22 \mathrm{~mm}$, medium thickness, groove almost closed; stipules $3-5 \mathrm{~mm}$, not very persistent, reduced, awl shaped; fruit spur leaves lanceolate elliptical acuminate to ovate abruptly acuminate, irregularly serrulate to wavy margined. Twigs in winter:

Branching erect, slightly spreading; bark slightly glossy, chocolate to auburn, lenticels 10 - 20 per internode, round; internode 30 - 40 per year, straight to only slightly zigzagged, somewhat keeled with side ridge bulges just below bud, pubescent above buds on upper 8 - 12 indernodes, distinctly pubescent beneath buds; buds $2.5 \times 3-2.7 \times 4 \mathrm{~mm} \cdot$, hlunt, elongate ovate to ovate, medium thickness, flat to rounding or slightly bulging, appressed to slightly spreading, somewhat ascew, apex and bud scale margins pubescent; bud scales ovate acute with $4-5$ out of seven showing, slightly ridged, pubescence scant; leaf scar narrow crescent shaped without subtending flange. 


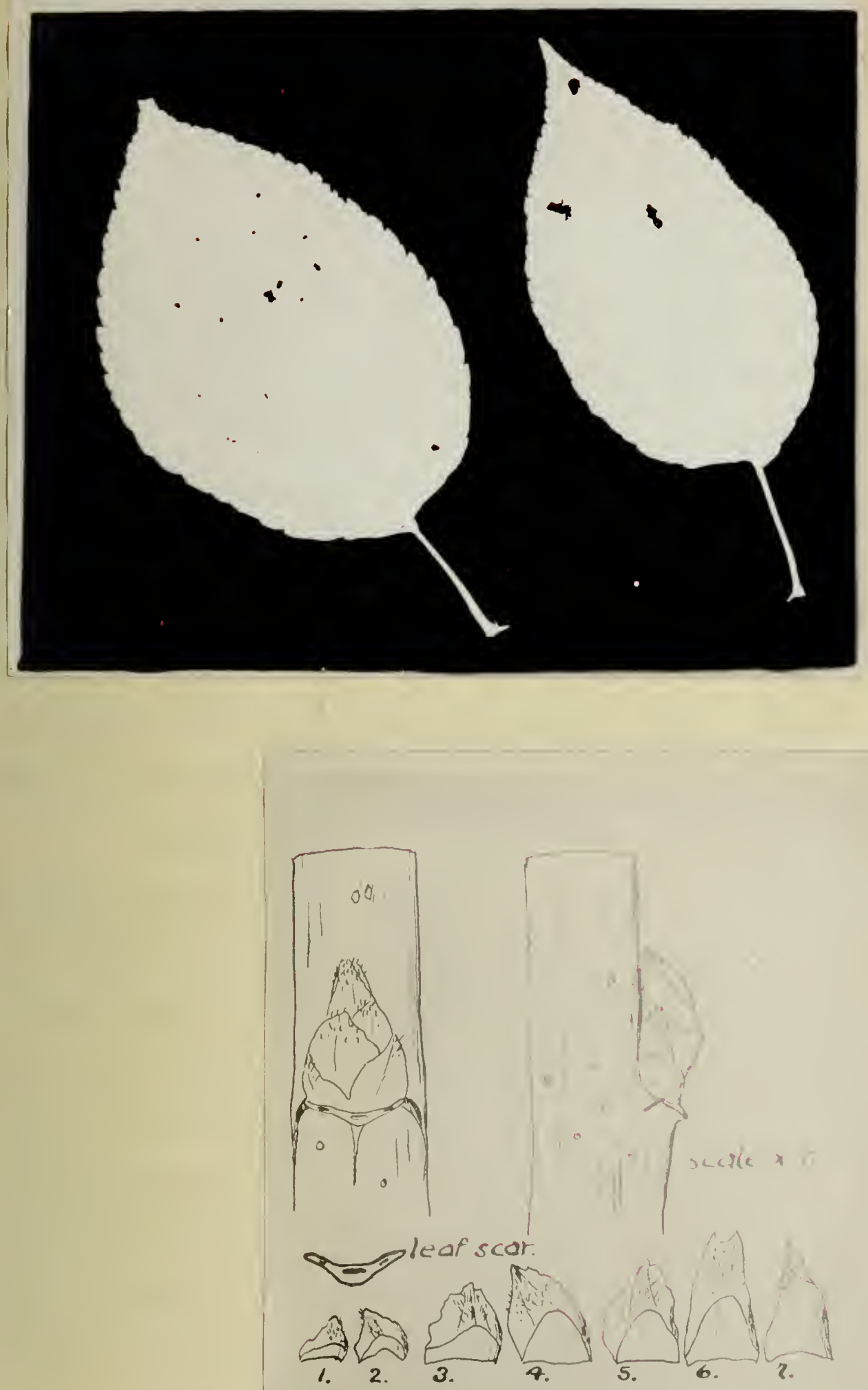

$$
\text { M. dioica. }
$$





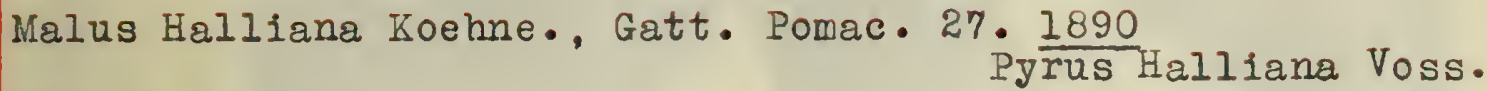
Leaves in fall:

Leaves $4-7 \mathrm{~cm}$, ovate, acute to slightly acuminate, frequently asymmetrical and shallowly notched at the sides; margin entire to wavg to evenly serrulate, without apical sinuses; veins flush to slightly impressed above, not prominent below, leaves thick leathery, leaf surfaces smooth and minutely areolate; glabred rous, petioles of mid rib backs/tinged; petioles $8-12 \mathrm{~mm}$., stout, terete, groove open and deep; stipules 7 - $10 \mathrm{~mm} \cdot$, scroll shaped, deepIy serrate with outer basal lobes spreading; terminal fruit spur lanceolate with a strongly decurrent base, evenly serrulate. Twigs in winter:

Branching erect, very spreading; bark dull, mahogany to diamine brown, lenticels ellongate elliptical to linear, $10-15$ per internode; internodes 30 - 40 per year, slightly zigzagged, somewhat keeled and ridged but not bulging below bud, glabrous except near terminal internode; buds $2.2 \times 3.7-2.3 \times 4 \mathrm{~mm}$. , elongate ovate to ovate acuminate, appressed, thin to medium, flat to rounding or slightly bulging at base, ascew with refracted tips, glabrous except for terminal hairs; bud scales ovate acute with 4 out of 5 showing, ridged, glabrous except for a few hairs at tip margins of 4 and 5; leaf scar wedge shaped without marked incurves, flanged. 



$$
100
$$



IV. Bibliography.

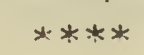

Nomenclature References.

Bailey, L. H. Cyclopedia of American Horticulture, 1904 , The Macmilian Co., New York.

De Candolle, A., Prodromus Systematis Naturalis Regni Vegetabilis

Schneider, C. K., Handbuch der Laubholzkunde.

Verlag Von Gustav Fischer, 1906.

Spach, E., Histoire de Vegetaux V. II ed. 1834.

Special Description and Terminology References.

Beach, S. A., The Apples of Ilew York.

Rpt.N.Y. Agr. Ex. Sta. 1903.

Brendel, Fred., The Tree in Winter.

III. Museum of Nat. History. 1876.

Foerste. Aug. I., The Identification of Trees in Winter, Bot. Gaz. 1892.

Hitchcock. A. S., The Opening of the Buds of Some Woody Plants. Trans. Acad. Sc. St. Louis, 1893.

Ridgway, Robt., Color Standards and Nomenclature. Published by Author, Washington D.C., 1912.

Robinson, John, Our Trees in Winter. Bul. Essex. Inst. Vol XII. 188(1)? 

Special Description and Terminology References (continued)

Sham, J. K., The technical Description of Apples. Bul. 159, Mass. Exp. Sta. 1914 .

Ward, H. M•, Trees. Vol. V. Cambridge Univ• Press, 1904 - 08. Wies-fiston, I., A Study in Growth and Development in Species of Malus. Master's Thesis, Univ. of Ill. 1915.

References on Keys to Woody Plants.

Apgar, A. C. Trees of Northern United States.

Blakeslee and Jarvis, Trees in Winter, N. Y.

The Macmillan Co. 1913.

Britton, N. I., North American Trees,

Henry Holt \& CO., N.Y. 1908.

Deam, C. C., Trees of Indiana.

Rept. Ind. St. Bd. For. 1911.

Hitchcock, A. S., A Key to Kansas Trees in Winter Condition. Print. Dept. Kan. State Agr. Col., Manhattan, 1901.

Otis, C. H., Michigan Trees. Univ. of Mich. Publ. 1912.

Sargent, C. S. Trees and Shrubs, Houghton, Mifflin \& Co. $1905-13$. 



\section{References on Keys to Woody Plants (continued)}

Schaffner, J. M., Key to the Genera of Ohio Woody Plants Based on Leaf and Twig Characters.

$$
\text { Ohio Nat. Vol. } 5,1905 \text {. }
$$

Schaffner, J. M. Field Manual of Trees.

$$
\text { R. G. Adams \& Co., Columbus, Ohio. } 1914 .
$$

Schneider, C.K., Dendrologische Winterstuaien

$$
\text { Verlag Von Gustav Fischer in Jena, } 1903 .
$$

Shirasawa, Homi, Die Japanischen Laubhblzer im Winterzustande. Tokio, Imp. Univ., Col. of Agr. Bul. Vol. II.No.5,1895.

Trelease, Wm., The Juglandaceae of United States 7th Rept. Mis. Bot. Gard. 1896.

Wiegand K. M. and Foxworthy, F. W. A Key to the Genera of Woody Plants in Winter.

Itbaca, N. Y. 1908 .

Wilkomb, Moritz, Deutsche Laubhritzer im Winter.

G. Shonfields Verlagungshandlung, Dresden, 1880 . 

. s.

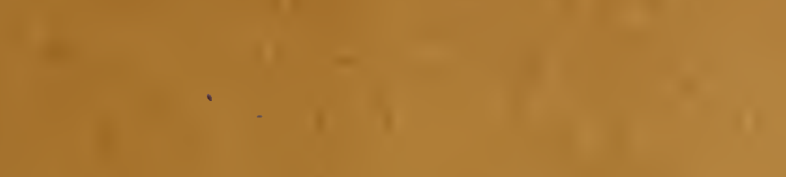

1.

-

I.

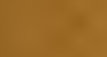

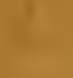

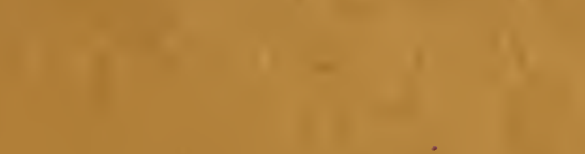

$+$

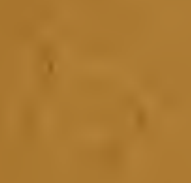

1.
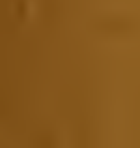

(isian

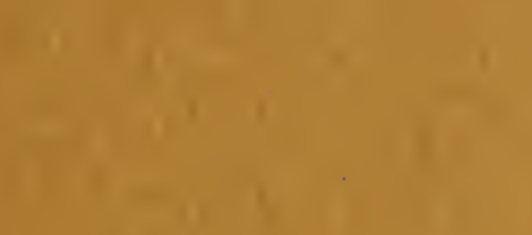

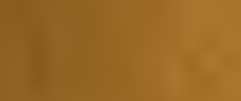

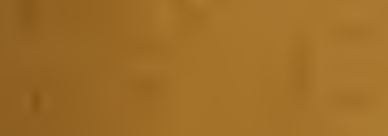

..

. 10.000

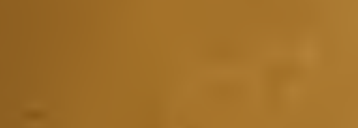
$y^{3}$

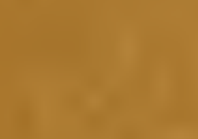

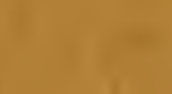

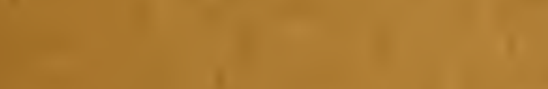
14

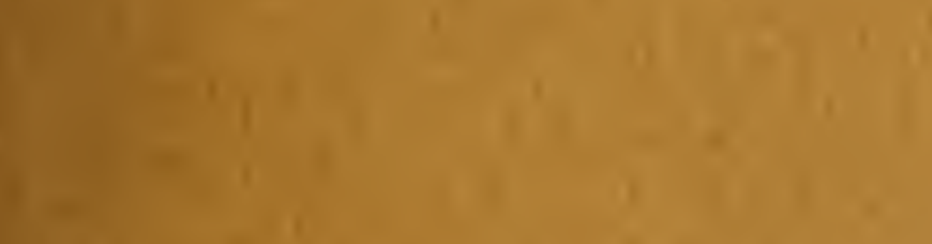

1

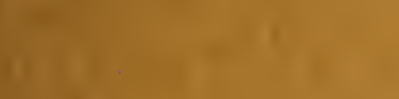

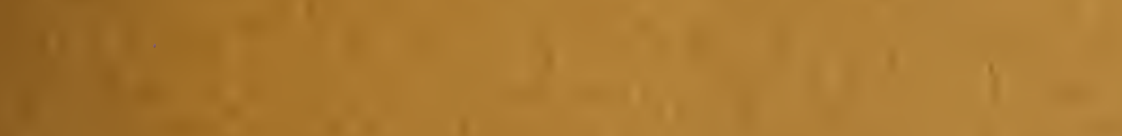

f

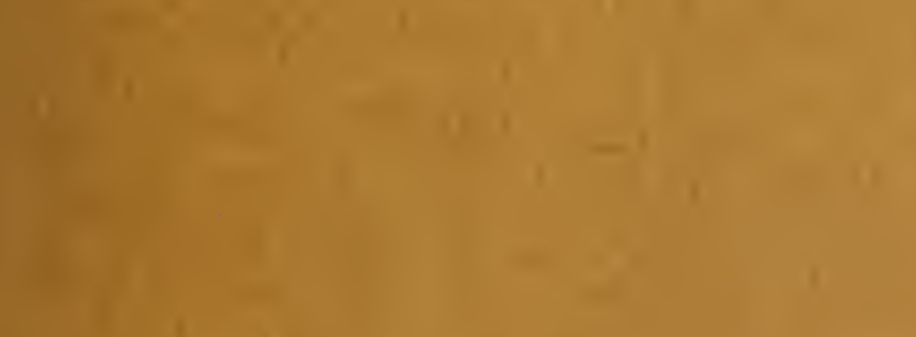

$1+$

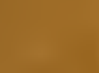

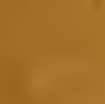

(1)

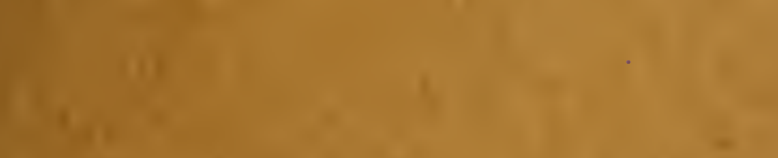

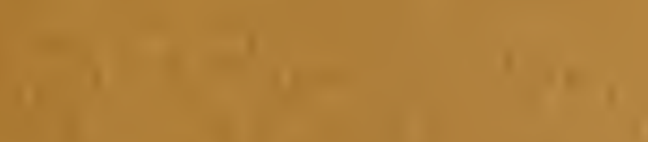

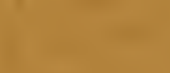

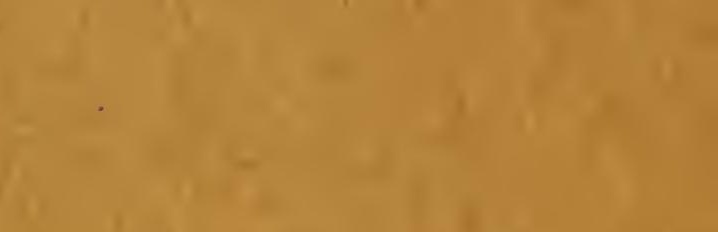

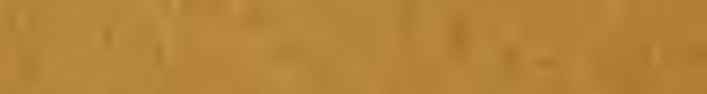

$1+4$

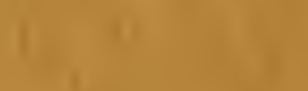

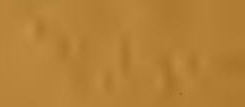

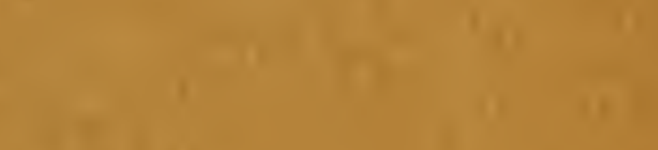

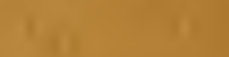
1
1
4

1

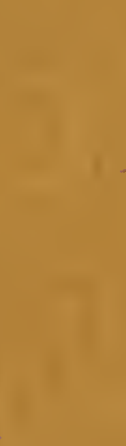

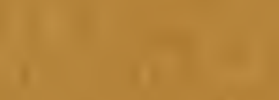

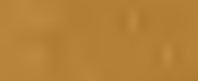

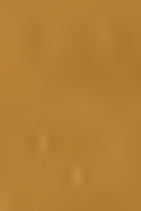

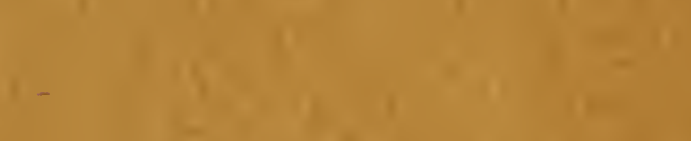

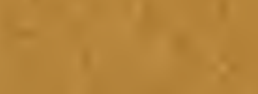

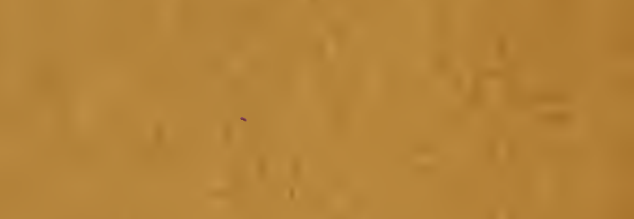

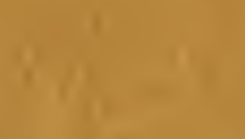

1

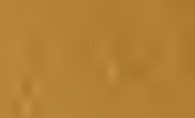

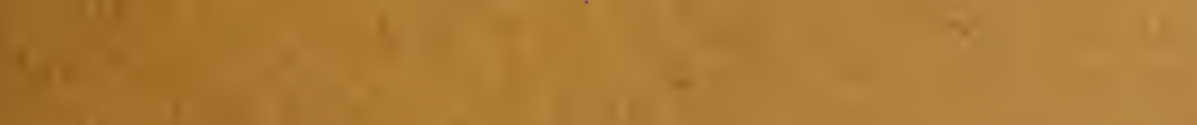

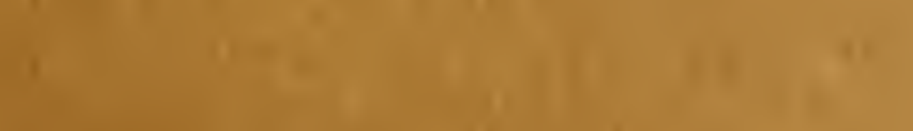

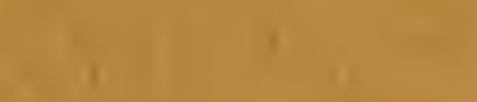

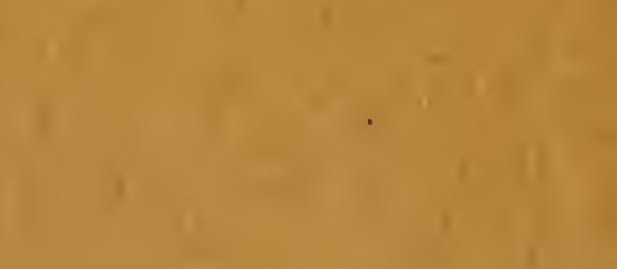

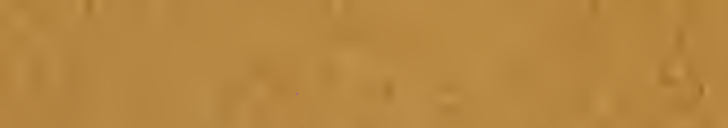

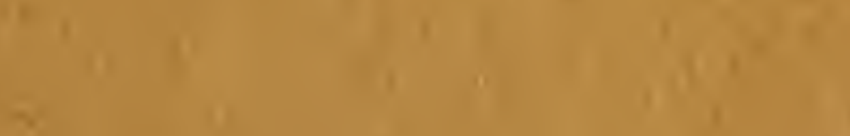


UNIVERSTTY OF ILLINOIS-URBANA

|||||||||||||||||||||||||||||||||||||||||||||||||

|||||||||||||||||||||||||||||||||||||||||||||||||||||||||||||

30112086831408

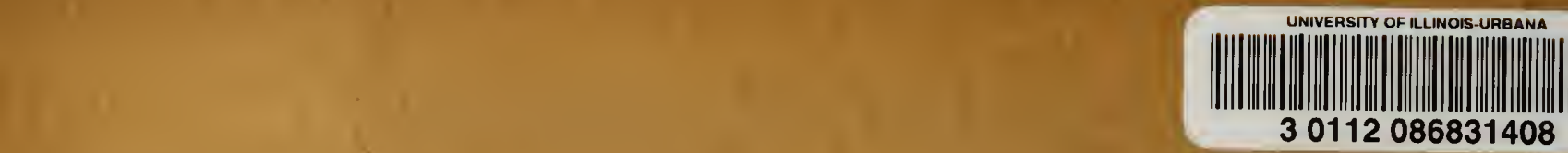

